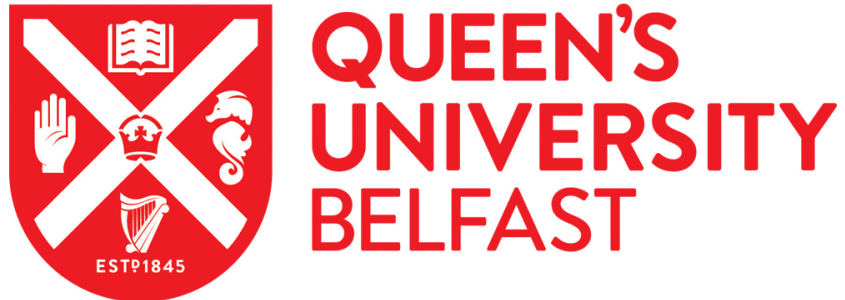

\section{Comparing the relationship between stature and later life health in six low and middle income countries}

McGovern, M. E. (2014). Comparing the relationship between stature and later life health in six low and middle income countries. The Journal of the Economics of Ageing, 4, 128-148.

https://doi.org/10.1016/j.jeoa.2014.09.011

\section{Published in:}

The Journal of the Economics of Ageing

\section{Document Version:}

Early version, also known as pre-print

Queen's University Belfast - Research Portal:

Link to publication record in Queen's University Belfast Research Portal

Publisher rights

(C) 2014 The Author(s)

\section{General rights}

Copyright for the publications made accessible via the Queen's University Belfast Research Portal is retained by the author(s) and / or other copyright owners and it is a condition of accessing these publications that users recognise and abide by the legal requirements associated with these rights.

Take down policy

The Research Portal is Queen's institutional repository that provides access to Queen's research output. Every effort has been made to ensure that content in the Research Portal does not infringe any person's rights, or applicable UK laws. If you discover content in the Research Portal that you believe breaches copyright or violates any law, please contact openaccess@qub.ac.uk. 


\title{
Comparing the Relationship Between Stature and Later Life Health in Six Low and Middle Income Countries*
}

\author{
Forthcoming in the Journal of the Economics of Ageing
}

\author{
Mark E. McGovern ${ }^{\dagger}$ \\ Harvard Center for Population and Development Studies \\ Department of Global Health and Population, Harvard School of Public Health
}

November 2014

\begin{abstract}
This paper examines the relationship between stature and later life health in 6 emerging economies, each of which are expected to experience significant increases in the mean age of their populations over the coming decades. Using data from the WHO Study on Global Ageing and Adult Health (SAGE) and pilot data from the Longitudinal Ageing Study in India (LASI), I show that various measures of health are associated with height, a commonly used proxy for childhood environment. In the pooled sample, a $10 \mathrm{~cm}$ increase in height is associated with between a 2 and 3 percentage point increase in the probability of being in very good or good self-reported health, a 3 percentage point increase in the probability of reporting no difficulties with activities of daily living or instrumental activities of daily living, and between a fifth and a quarter of a standard deviation increase in grip strength and lung function. Adopting a methodology previously used in the research on inequality, I also summarise the height-grip strength gradient for each country using the concentration index, and provide a decomposition analysis.
\end{abstract}

JEL Classification: I12, I14, D30, O15

Keywords: Early Life Conditions, Health, Ageing, Height, Inequality, Low and Middle Income Countries, LASI, SAGE

${ }^{*}$ I thank Slawa Rokicki, two anonymous referees, the editors, Grant Miller and other participants at the HarvardStanford Conference on the Economics of Population Aging in China and India for comments. I gratefully acknowledge funding from the Program on the Global Demography of Aging, which is supported by the US National Institute on Aging, Grant No. 1 P30 AG024409-09. This paper uses data from the World Health Organization Study on Global AGEing (SAGE). SAGE is supported by the US National Institute on Aging through Interagency Agreements (OGHA 04034785; YA1323-08-CN-0020; Y1-AG-1005-01) and through a research grant (R01-AG034479). This paper also uses data from the Longitudinal Aging Study in India (LASI) pilot, which is funded by the US National Institute on Aging (R21AG034443, R01AG030153, and R03AG043052). The published version of this article is available at http://dx.doi.org/10.1016/j.jeoa.2014.09.011.

${ }^{\dagger}$ Email: mcgovern@hsph.harvard.edu. Address: 9 Bow Street, Cambridge, MA 02138, USA. 


\section{Introduction}

Comparison of cross country health differences provides an opportunity to evaluate the efficacy of different policies and institutions adopted in these locations (Kapteyn, 2010). The recent emergence of harmonised micro level datasets has the potential to contribute to this discussion by permitting the comparison of survey respondents on the basis of their own individual characteristics, and not just aggregate indicators such as life expectancy. This is particularly true in the field of ageing research, where a number of studies now collect standardised information on a wide range of characteristics (Banks and Smith, 2012). These include the Health and Retirement Study (HRS) in the US, the English Longitudinal Study of Ageing (ELSA) in the UK, and the Survey of Health, Ageing and Retirement in Europe (SHARE). A welcome development is the introduction of similar initiatives in lower and middle income countries. These include the WHO study on Global Ageing and Adult Health - SAGE (Kowal et al., 2012), the Longitudinal Ageing Study in India - LASI (Arokiasamy et al., 2012), and the China Health and Retirement Longitudinal Study - CHARLS (Zhao et al., 2012).

An understanding of the consequences of population ageing is likely to be of particular interest to lower and middle income countries due to the fact that the older portion of their populations is expected to grow rapidly over the coming decades. For example, by 2050 more than 750 million individuals over the age of 60 will live in India and China, constituting over a third of the world's total population in that demographic (Chatterji et al., 2008). Increases in morbidity are likely to accompany this (Bloom et al., 2011), and therefore international comparisons using micro level data will be useful in assessing the extent to which changes in morbidity are likely to occur, potential variation in the consequences of population ageing across countries, and whether it is possible to identify the factors which predict healthy ageing. The existing literature on international comparisons typically evaluates differences in means or regression coefficients across higher income countries, as described in the review by Banks and Smith (2012). For example, Banks et al. (2006) discuss health disparities between England and the US using ELSA and the HRS. Examples of papers which take advantage of newer data include Chatterji et al. (2008), who conduct a similar analysis for India and China. Naidoo et al. (2010) and Basu and Millett (2013) evaluate cross national differences in health using data from the SAGE study.

One aspect of ageing where there is particular scope for interesting comparisons across countries relates to the role of the life cycle, and the extent to which initial health affects adult outcomes. An established literature links early life conditions to later life wellbeing, including both health and economic outcomes (Almond and Currie, 2011a,b). However, as with other aspects of ageing, most of the existing research in this field has also focused on higher income nations. The inclusion of retrospective life history modules in studies such as ELSA, SHARE, and the HRS is partly a reflection of the attention the lasting implications of childhood circumstance have been receiving (Smith, 2009). For example, Banks et al. (2011) find that the transmission of poor early life health into adverse adult outcomes is greater in the US than the UK.

A number of recent papers have also provided evidence on this topic for low and middle income countries, see Currie and Vogl (2013) and McEniry (2013) for an overview. For example, BeltránSánchez et al. (2011) examine the long term correlates of education in Mexico, while DeGraff and Wong (2014) investigate the influence of broader childhood environment in the same country. 
McEniry and Palloni (2010) examine the long-run impact of disease and nutrition in childhood using data from Puerto Rico. The newly developed ageing studies, such as the LASI or SAGE data used in this paper, also provide a useful original source of information. For example, Smith et al. (2012) use data from CHARLS and find a significant association between childhood environment and the outcomes of Chinese respondents, which is consistent with the evidence from Mexico and Puerto Rico.

There are a number of reasons why a comparison of the association between early life conditions and later outcomes in lower and middle income countries is specifically of interest. Firstly, their ageing populations are likely to impact relatively more significantly on these societies, given the comparatively more limited resources available to their governments. Secondly, given that the initial environment experienced by children in these countries is likely to have been more adverse than that experienced by children in higher income countries, the impact of early life conditions on this cohort of adults may be expected to be even greater (Currie and Vogl, 2013). For example, stunting (growth restriction as defined by being 2 standard deviations below the expected height for age) is rare in high income countries, but affects $40 \%$ of children in Africa (Black et al., 2008). Even if initial endowments were similar across countries, differences in the association between childhood circumstance and later outcomes could have the potential to add to our understanding of the factors underlying variation in aggregate outcomes (Banks et al., 2011). Finally, a cross country comparison could provide a useful first indication as to the extent to which the role of early life conditions can be mitigated by macro level factors.

In addition to this primary motivation of investigating the extent of variation in the correlates of initial environment, an additional contribution of this paper is that I introduce an alternative approach for measuring the association between early life conditions and later health. Comparisons based on regression coefficients from the typical analyses in these studies represent the average association in the population, and do not necessarily describe whether inequality is concentrated among the least well off, or evenly spread across the distribution of socioeconomic status. Therefore, I also adopt a more flexible methodology for establishing the extent to which the relationship between childhood environment and adult health varies across countries. The inequality literature in economics typically uses the concentration curve and the concentration index as a summary measure for describing gradients in health and socioeconomic variables (Wagstaff et al., 1991). Specifically, the concentration curve defines the share of the outcome of interest which is accounted for by the cumulative proportion of individuals in the population ranked from the least well off to the most well off (O'Donnell et al., 2008). This approach has been previously used in a variety of applications, including to determine the extent of inequality in health (van Doorslaer and Koolman, 2004), malnutrition (Wagstaff et al., 2003), birth weight (Madden, 2013a), health care use (Layte and Nolan, 2014), BMI (Madden, 2013b; Walsh and Cullinan, 2014), health behaviours (Hudson et al., 2014), and vaccination (Doherty et al., 2014).

This existing literature generally examines income related inequality, however, measures of household income in childhood are rarely available outside of cohort studies. Therefore, height is often used as the measure of initial environment in studies on the lasting impact of childhood circumstance (Akachi and Canning, 2010; Case and Paxson, 2008, 2010; Lee and Smith, 2014; Smith et al., 2012). When compared to using self-reported health in childhood dereived from retrospective questionnaires, results using height are generally comparable (e.g. Banks et al., 2011), even though these measures are not always highly correlated (Smith et al., 2012). The use of height as a proxy 
for early life conditions is also supported by studies which examine the determinants of stature, for example height is related to initial disease environment (Bozzoli et al., 2009), nutritional intake (Walker et al., 2007), and birth weight (McGovern, 2014). Historical improvements in height in western countries since the 18th century are believed to be at least partly caused by advances in nutritional status (Fogel, 2004), and the link between average height and economic development is also believed to be driven by the relationship between nutritional intake and early environment (Strauss and Thomas, 1998). Improvements in adult life expectancy and declining mortality among the young have been associated with increases in height among the same cohorts (Crimmins and Finch, 2006). The use of anthropometric data in this context is documented in the overviews by Steckel (2008) and Steckel (2009).

It is important to acknowledge that there are limitations to using height as a proxy for early life conditions, an issue which I discuss in more detail in section 2. These include the fact that stature may be a noisy measure of initial environment (especially at the individual level), there are many possible determinants of height which are difficult to isolate, including nutritional status, disease environment and genetics, and finally, there are diverse pathways through which height could affect later outcomes, including potentially direct advantages due to size itself (rather than latent effects of early life conditions). Therefore, results from studies which rely on height should be interpreted with these limitations in mind. In this paper, I do not make any claims about the results being interpretable as causal effects, as that is not possible with the available data. Instead, the associational analysis presented here can be viewed as being part of the initial steps into investigating the relationship between early life conditions and later outcomes in lower and middle income countries.

Using data on 6 countries from SAGE (China, Ghana, India, Mexico, Russia and South Africa) and pilot data from LASI, I examine the association between stature and four health measures (self-rated health, difficulties with activities of daily living (ADL) and instrumental activities of daily living (IADL), grip strength and lung function). Along with height, the latter three outcomes have the advantage of being objectively measured, are easily comparable across countries, and are commonly collected in many surveys. In addition, grip strength and lung function have been shown to be important measures of frailty in later life (Cook et al., 1995; Mannino et al., 2003; Rantanen et al., 1999; Sharp et al., 1997). I begin with a regression analysis comparing the association of height with each of the health outcomes by country. Then, I illustrate the use of concentration curves by measuring the cumulative share of grip strength which accrues to survey respondents ranked according to their height. Finally, I compare this summary measure of inequality across countries. An additional advantage of this approach is that it is possible to decompose this inequality into its constituent components based on other observable characteristics.

The rest of the paper is structured as follows. Section 2 describes the data and approach. Section 3 presents a regression analysis for measuring the association of height with adult health, following the approach which is typically used to compare differences in early life health associations across countries. Section 4 then outlines the methodology for implementing the concentration curve approach, and provides results. Section 5 concludes. 


\section{Data and Methods}

\subsection{Data}

This paper uses data from the World Health Organization's Study on Gobal Ageing and Adult Health (SAGE), a longitudinal nationally representative study of individuals in six lower and middle income countries (China, Ghana, India, Mexico, Russia and South Africa). The survey instrument was designed to be comparable to other ageing surveys, however unlike the HRS, ELSA and SHARE, the population under the age of 50 were also targeted as a separate cohort alongside individuals over the age of 50. The former cohort is relatively small, and was included in order to provide a potential comparison group for older respondents. ${ }^{1}$ In order to reflect the previous research which is most similar to this study (Smith et al., 2012), I restrict the sample to those over the age of 45, which is the age cut-off for inclusion used in CHARLS. Wave one of the SAGE study was conducted between 2007 and 2010, although a smaller baseline cohort did participate in wave 0 in 2002-2004. Data collection for wave 2 will take place in 2013-2014. The SAGE data are publically available from the WHO. ${ }^{2}$ For comparison, I also include data from the pilot round of the Longitudinal Ageing Study in India (LASI), which was conducted in $2010 .^{3}$ As with SAGE, LASI is designed to be comparable with existing ageing studies. The pilot includes data from 1,683 respondents aged 45 years or older (and their spouses) in four states (Punjab, Rajasthan, Kerala, and Karnataka), of whom 1,305 participated in biomarker data collection. LASI is designed to be representative of both the country as a whole and its constituent states, and later waves of the full survey will follow more than 50,000 participants longitudinally (Arokiasamy et al., 2012; Bloom et al., 2014).

Table 1 shows descriptive statistics for the main variables for each country in the analysis sample. ${ }^{4}$ In addition to restricting respondents to be aged over 45, preliminary analysis indicated the presence of outliers, so the main analysis sample also excludes respondents below the 1st and above the 99th height percentile. Height, the main explanatory variable of interest, is objectively measured in centimetres (CM) using a stadiometer. Self-reported health is measured on a scale of 1-5 (very good, good, moderate, bad, very bad). ${ }^{5}$ I construct an indicator for whether the respondent was in the top two health categories (very good or good). The SAGE questionnaire includes a number of items on activities of daily living (ADL), and instrumental activities of daily living (IADL). ${ }^{6}$ Respondents are presented with a list of activities and asked to rate their difficulty with each on a scale of 1 (none) to 5 (severe). I create an indicator variable for whether respondents reported having no difficulties with all of the 22 activities (sitting, walking, standing up, standing, climbing, crouching, picking up, household responsibilities, community activities, extending arms, concentration, walking, bathing, dressing, working, carrying, moving inside the home, eating, getting up from lying down, getting to and using the toilet, getting to places, and getting out of the home). I also considered more complicated formulations, such as a frailty index approach (Harttgen et al., 2013), but found similar associations with height using this method.

\footnotetext{
${ }^{1}$ For further details on the sampling procedure, see www.who.int/healthinfo/sage/cohorts/en/index2.html.

${ }^{2}$ www.who.int/healthinfo/sage/en/.

${ }^{3}$ LASI data are available from the Gateway to Global Aging Data website: www.g2aging.org.

${ }^{4}$ It is apparent from table 1 that there missing values for some variables. As a robustness check, I have estimated models based on multiple imputation and found similar results.

${ }^{5}$ For LASI, the last three categories are worded slightly differently (fair, poor and very poor).

${ }^{6}$ Due to questionnaire differences in the LASI survey, I focus on SAGE for the ADL/IADL analysis.
} 
Table 1: Descriptive Statistics

\begin{tabular}{|c|c|c|c|c|c|c|c|c|c|c|c|c|c|c|c|c|}
\hline & \multicolumn{4}{|c|}{ India (SAGE) } & \multicolumn{4}{|c|}{ India (LASI) } & \multicolumn{4}{|c|}{ China } & \multicolumn{4}{|c|}{ South Africa } \\
\hline & Median & Mean & $\mathrm{SD}$ & $\mathrm{N}$ & Median & Mean & $\mathrm{SD}$ & $\mathrm{N}$ & Median & Mean & $\mathrm{SD}$ & $\mathrm{N}$ & Median & Mean & $\mathrm{SD}$ & $\mathrm{N}$ \\
\hline Age & 55 & 56.73 & 10.5 & 6,930 & 55 & 56.99 & 10.2 & 1,147 & 54 & 56.26 & 10.1 & 12,769 & 52 & 55.93 & 10.2 & 3,464 \\
\hline Height (CM) & 158 & 158.05 & 9.2 & 6,930 & 157.5 & 158.17 & 9.2 & 1,147 & 160.5 & 160.63 & 8.1 & 12,769 & 159 & 159.02 & 8.6 & 3,464 \\
\hline Very Good or Good Self-Reported Health & 0 & 0.35 & 0.5 & 6,930 & 1 & 0.59 & 0.5 & 1,145 & 0 & 0.4 & 0.5 & 12,749 & 0 & 0.42 & 0.5 & 3,458 \\
\hline No Difficulties with ADL/IADL & 0 & 0.30 & 0.5 & 6,930 & & & & & 1 & 0.76 & 0.4 & 12,769 & 0 & 0.49 & 0.5 & 3,464 \\
\hline Grip Strength (KG: 0-100) & 21 & 22.34 & 10.3 & 6,597 & 19.5 & 20.04 & 9.3 & 1,022 & 29 & 29.05 & 12.3 & 12,429 & 29 & 35.15 & 19.1 & 3,003 \\
\hline Lung Capacity (Litres: 0-10) & 1.6 & 1.72 & 0.9 & 6,108 & 1.3 & 1.53 & 1.1 & 735 & 2.5 & 2.48 & 0.8 & 12,633 & 2.1 & 2.28 & 1 & 3,175 \\
\hline Male & 1 & 0.56 & 0.5 & 6,930 & 0 & 0.48 & 0.5 & 1,147 & 1 & 0.51 & 0.5 & 12,769 & 0 & 0.48 & 0.5 & 3,464 \\
\hline Mother Had No Formal Education & 1 & 0.87 & 0.3 & 6,807 & 1 & 0.82 & 0.4 & 1,147 & 1 & 0.83 & 0.4 & 12,265 & 1 & 0.55 & 0.5 & 2,575 \\
\hline \multirow[t]{3}{*}{ Father Had No Formal Education } & 1 & 0.64 & 0.5 & 6,627 & 1 & 0.73 & 0.4 & 1,147 & 1 & 0.64 & 0.5 & 12,119 & 0 & 0.44 & 0.5 & 2,406 \\
\hline & \multicolumn{4}{|c|}{ Ghana } & \multicolumn{4}{|c|}{ Mexico } & \multicolumn{4}{|c|}{ Russia } & & & & \\
\hline & Median & Mean & $\mathrm{SD}$ & $\mathrm{N}$ & Median & Mean & $\mathrm{SD}$ & $\mathrm{N}$ & Median & Mean & $\mathrm{SD}$ & $\mathrm{N}$ & & & & \\
\hline Age & 52 & 56.42 & 11.8 & 4,309 & 55 & 58.16 & 11.1 & 2,102 & 57 & 60.05 & 11 & 3,362 & & & & \\
\hline Height $(\mathrm{CM})$ & 163.2 & 163.2 & 7.9 & 4,309 & 157.4 & 157.08 & 9.1 & 2,102 & 164 & 164.29 & 8.1 & 3,362 & & & & \\
\hline Very Good or Good Self-Reported Health & 1 & 0.54 & 0.5 & 4,308 & 0 & 0.42 & 0.5 & 2,054 & 0 & 0.16 & 0.4 & 3,359 & & & & \\
\hline No Difficulties with ADL/IADL & 0 & 0.45 & 0.5 & 4,309 & 0 & 0.42 & 0.5 & 2,102 & 1 & 0.66 & 0.5 & 3,362 & & & & \\
\hline Grip Strength (KG: 0-100) & 28 & 27.06 & 12.6 & 3,950 & 21 & 23 & 8.6 & 1,854 & 28 & 29.1 & 12.1 & 2,791 & & & & \\
\hline Lung Capacity (Litres: 0-10) & 2 & 2.07 & 0.9 & 3,734 & 2.5 & 2.62 & 0.8 & 1,900 & 2.7 & 2.9 & 1 & 2,416 & & & & \\
\hline Male & 1 & 0.53 & 0.5 & 4,309 & 0 & 0.47 & 0.5 & 2,102 & 0 & 0.38 & 0.5 & 3,362 & & & & \\
\hline Mother Had No Formal Education & 1 & 0.93 & 0.3 & 4,267 & 1 & 0.59 & 0.5 & 1,822 & 0 & 0.15 & 0.4 & 3,166 & & & & \\
\hline Father Had No Formal Education & 1 & 0.82 & 0.4 & 4,209 & 0 & 0.47 & 0.5 & 1,716 & 0 & 0.1 & 0.3 & 3,005 & & & & \\
\hline
\end{tabular}

Note: The analysis sample is restricted to those over the age of 45, and those between the 1st and 99th percentiles of the height distribution. Descriptive statistics are weighted. Very good or good self-reported health is defined as being in the top two categories of five self-reported health categories. No difficulties with activities of daily living (ADL) or instrumental activities of daily living (IADL) is measured for SAGE only, and is defined as having no difficulties with sitting, walking, standing up, standing, climbing, crouching, picking up, household responsibilities, community activities, extending arms, concentration, walking, bathing, dressing, working, carrying, moving inside the home, eating, getting up from lying down, getting to and using the toilet, getting to places, and getting out of the home. Source: WHO SAGE wave 1 and LASI Pilot. 
Grip strength is measured using a dynamometer (in kilograms (KG), where 0 represents the least strong), and the variable used represents the mean of two attempts from the dominant hand. Lung function refers to forced vital capacity (FVC) from maximal expiratory effort (in litres, where 0 represents the weakest). Figures A1-A3 in the appendix illustrate the distribution of each of these variables by country. Median age ranges from 52 in Ghana and South Africa to 57 in Russia. The two Indian surveys from SAGE and LASI appear to be reasonably comparable on the basis of these descriptive statistics, apart from self-rated health, which could reflect wording differences in the questionnaires. In general, comparing self-rated health across countries can be problematic due to differences in the way in which respondents interpret and respond to the question (Salomon et al., 2004). Mean height is greatest in Russia $(164 \mathrm{~cm})$, and lowest in Mexico $(157 \mathrm{~cm})$, while mean grip strength ranges from 20 in India (LASI), to 35 in South Africa, and lung function ranges from 1.5 in India (LASI) to 2.9 in Russia. $76 \%$ of Chinese have no difficulty with any ADL or IADL, compared to $30 \%$ in India (SAGE). Therefore, not all of these indicators give the same country rankings, which may reflect that underlying frailty is multidimensional, or that the data contain some element of measurement error. The only other variables in the data which are likely determined prior to the respondents' childhood are sex, ethnicity, and whether their parents had any formal education. The data include a wide variety of other information on the socio-demographic characteristics of respondents; however these are likely to at least partly represent the outcome of early life conditions and are therefore excluded. It should be noted that using them in the analysis had little effect on the conclusions.

\subsection{Interpreting Height-Health Associations}

Interpreting associations between height and measures of health status (such as estimates obtained from regression coefficients) is complicated for a number of reasons. Firstly, there is the potential for age related physical stature decline. Previous research has demonstrated that this phenomenon begins to occur in later life (Huang et al., 2013), and therefore the height data collected in this paper potentially incorporate some of this age effect and are unlikely to reflect maximum height. However, Fernihough and McGovern (2014) have investigated this issue specifically in the context of the relationship between height, grip strength and lung function, and demonstrate that the bias which arises from stature loss in models with health outcomes which control for age is likely to be negligible.

Secondly, the data likely contain measurement error. Figures A1-A3 in the appendix suggest evidence of heaping. In figure A1 this is particularly apparent in the height distributions for Russia, South Africa and India (LASI). The grip strength distribution for South Africa also has a larger right hand tail than the other surveys, and the mean value is also higher than the other countries. Therefore, it is reasonable to assume that both the outcome and main explanatory variables are measured with error, which would tend to attenuate the coefficients presented and increase the associated confidence intervals, assuming this measurement error was random.

Thirdly, height is an imperfect measure of early life conditions. Stature represents a composite of various factors, including infant and childhood health, nutrition and disease environment, but also other inputs such as genetic endowment. While some studies have found little evidence of ethnic differences in growth potential (Habicht et al., 1974), others have found that height may be a noisy proxy for initial environment (Deaton, 2007). See Behrman and Deolalikar (1988) for a discussion of 
the socioeconomic determinants of height in childhood. There are other factors which could induce a correlation between height and later outcomes which is not directly due to early life conditions, for example the known association between height, cognitive ability and wages (Böckerman and Vainiomäki, 2013; Case and Paxson, 2008; LaFave and Thomas, 2013; Sohn, 2014; Vogl, 2014). Size can be considered an outcome of early life environment (Walker et al., 2007; McGovern, 2014), and size itself could confer health benefits or other advantages. Height is a measure of size, therefore, as with the existing literature which uses stature, the results presented in this paper potentially incorporate some aspect of size. Size could be associated with health outcomes independently of true health status, particularly for grip strength and lung function. Taller respondents could record greater grip strength but not necessarily be any healthier than their shorter counterparts. For example, some papers standardise grip strength for height (Meijer et al., 2011; Syddall et al., 2003) when using it as a marker for health status. It is difficult to assess how this potential size effect impacts on estimating associations between early life environment and later health without other direct measures of childhood conditions, however the consistent association of height with other health outcomes in this paper (including self-reported health and difficulties with ADL and IADL) and the rest of the literature suggests that this association is unlikely to be spurious.

More generally, there are two potential pathways through which early life conditions could affect later outcomes (Case and Paxson, 2008; Van den Berg et al., 2009). One mechanism through which early life conditions affect later outcomes can be termed the direct pathway. This mechanism is commonly defined as operating through a direct weakening of a persons underlying health status due to adverse initial nutrition, disease or health environment, such that they experience worse health in later life due to the fact that their cardiovascular system (for example) has been structurally damaged. The Barker Hypothesis is one specific example of this pathway (Barker, 1995). A second mechanism can be termed the indirect pathway. This reflects the fact that those with worse early life environments could experience other disadvantages above and beyond a direct weakening of underlying health status, which could in turn affect later outcomes. For example, genetic endowments could affect height and adult wellbeing via health, education, or socioeconomic status. Therefore, while height associations support the hypothesis that early life conditions are important for later outcomes, the specific mechanisms cannot be isolated by this kind of analysis (Case and Paxson, 2010).

Finally, the outcomes used in the analysis (self-reported health, difficulties with ADL and IADL, grip strength and lung function) are proxies for underlying health status. All have their own advantages and disadvantages, for example self-reported health is correlated with mortality (Mossey and Shapiro, 1982), but is also subjective and could be affected by unobserved individual differences in how respondents rank health states (Salomon et al., 2004).

In summary, height-health associations do not typically allow for causal interpretations. Height has many potential determinants, and it is generally difficult to isolate the particular mechanism underlying these associations. However, as height is mainly determined early in life, it has nevertheless been considered as a useful means of investigating the lasting impact of childhood conditions, and evaluating the disadvantages suffered in later life by those who experience adverse early life environment, incorporating both the direct (weakening of underlying health status) and indirect (genetics, size, socioeconomic status, education, cognitive ability) pathways (Case and Paxson, 2010). 


\section{Regression Analysis}

I begin by presenting results from regressions of the outcomes of interest (self-rated health, no difficulties with ADL and IADL, grip strength and lung function) on height in the pooled sample. I stratify all analyses by sex, as the previous literature suggests that the influence of early life environment may be stronger for men (Drevenstedt et al., 2008), and there are biological sex differences which could affect the associations between height and health (Lee and Smith, 2014). I consider a number of alternative specifications for these regressions, shown in table 2 (men) and table 3 (women). I first control for age only (which is equivalent to cohort in this data as it is a single cross section), using either a linear effect (column 1) or using 5 year age group indicator variables (column 3). I also show results using log height (as opposed to height in centimetres for the other models) as the main independent variable (column 2) (Lee and Smith, 2014). I repeat these three specifications in columns 4-6, with the addition of controls for country, ethnicity, and parental education. I use OLS for each outcome, with standard errors adjusted for clustering at the primary sampling unit (PSU) level. Following Deaton (1997), I do not weight the regressions, although doing so does not greatly affect results. For self-rated health and no difficulties with ADL and IADL, the outcomes are binary, and the regression coefficient for height can be interpreted as the change in the probability of the outcome occurring associated with a $1 \mathrm{~cm}$ increase in height. For grip strength and lung function, I calculate a $\mathrm{Z}$ score using the pooled sample (separately for each sex). In this case, the coefficient on height can be interpreted as the expected change in standard deviation units of the outcome for a $1 \mathrm{~cm}$ increase in stature. Height is entered linearly in the regressions, as alternative specifications do not indicate that there are either diminishing or increasing returns to stature.

In general, results are consistent across specifications and the addition of controls or alternative specification of the age effect does not greatly affect estimates of the association between height and health status, though additional controls do tend to reduce the size of the association, indicating that characteristics such as ethnicity and parental socioeconomic status may explain some of the unadjusted relationship. For example, in the model for grip strength among men, a $1 \mathrm{~cm}$ increase in height is associated with a 0.030 standard deviation increase in grip strength in the model with age (table 2, panel 1, column 1), a 0.031 standard deviation increase in the model with age group (table 2, panel 1, column 3), a 0.026 standard deviation increase in the model with age and controls (table 2, panel 1, column 4), and a 0.027 standard deviation increase in the model with age group and controls (table 2, panel 1, column 6). One outcome which is not consistent with this pattern is self-rated health for women, where the models with no controls show no significant association with height.

Next, I estimate regression models for health and height, stratified by country. Given the results in tables 2 and 3, I focus on the specification with controls and age as a linear effect. 
Table 2: The Association Between Stature and Later Life Health (Men)

\begin{tabular}{lcccccc}
\hline & Model 1 & Model 2 & Model 3 & Model 4 & Model 5 & Model 6 \\
& OLS & OLS & OLS & OLS & OLS & OLS \\
\hline & \multicolumn{7}{c}{ Outcome: Grip Strength $($ Men) } \\
\cline { 2 - 7 } Height Coefficient & $0.030^{* * *}$ & $4.968^{* * *}$ & $0.031^{* * *}$ & $0.026^{* * *}$ & $4.207^{* * *}$ & $0.027^{* * *}$ \\
& $(0.002)$ & $(0.284)$ & $(0.002)$ & $(0.002)$ & $(0.262)$ & $(0.002)$ \\
Observations & 14,768 & 14,768 & 14,274 & 14,755 & 14,755 & 14,274 \\
R-squared & 0.119 & 0.119 & 0.123 & 0.262 & 0.262 & 0.250 \\
\hline
\end{tabular}

\begin{tabular}{lcccccc} 
& \multicolumn{5}{c}{ Outcome: Lung Function (Men) } \\
\cline { 2 - 7 } Height Coefficient & $\begin{array}{c}0.036^{* * *} \\
(0.002)\end{array}$ & $\begin{array}{c}5.878^{* * *} \\
(0.272)\end{array}$ & $\begin{array}{c}0.037^{* * *} \\
(0.002)\end{array}$ & $\begin{array}{c}0.028^{* * *} \\
(0.001)\end{array}$ & $\begin{array}{c}4.659^{* * *} \\
(0.218)\end{array}$ & $0.030^{* * *}$ \\
& & & & & $0.001)$ \\
Observations & 14,329 & 14,329 & 13,960 & 14,318 & 14,318 & 13,960 \\
R-squared & 0.108 & 0.108 & 0.117 & 0.265 & 0.265 & 0.260 \\
\hline
\end{tabular}

\begin{tabular}{|c|c|c|c|c|c|c|}
\hline \multirow[b]{2}{*}{ Height Coefficient } & \multicolumn{6}{|c|}{ Outcome: Very Good or Good Self-Reported Health (Men) } \\
\hline & $\begin{array}{c}0.002^{* * *} \\
(0.001)\end{array}$ & $\begin{array}{c}0.335^{* * *} \\
(0.108)\end{array}$ & $\begin{array}{c}0.002^{* * *} \\
(0.001)\end{array}$ & $\begin{array}{c}0.003^{* * *} \\
(0.001)\end{array}$ & $\begin{array}{c}0.468^{* * *} \\
(0.106)\end{array}$ & $\begin{array}{c}0.003^{* * *} \\
(0.001)\end{array}$ \\
\hline Observations & 15,646 & 15,646 & 15,101 & 15,632 & 15,632 & 15,101 \\
\hline R-squared & 0.045 & 0.045 & 0.041 & 0.081 & 0.081 & 0.072 \\
\hline \multirow[b]{2}{*}{ Height Coefficient } & \multicolumn{6}{|c|}{ Outcome: No Difficulties with ADL/IADL (Men) } \\
\hline & $\begin{array}{c}0.006^{* * *} \\
(0.001)\end{array}$ & $\begin{array}{c}0.973^{* * *} \\
(0.151)\end{array}$ & $\begin{array}{c}0.006^{* * *} \\
(0.001)\end{array}$ & $\begin{array}{c}0.003^{* * *} \\
(0.001)\end{array}$ & $\begin{array}{c}0.515^{* * *} \\
(0.113)\end{array}$ & $\begin{array}{c}0.003^{* * *} \\
(0.001)\end{array}$ \\
\hline Observations & 15,132 & 15,132 & 15,132 & 15,132 & 15,132 & 15,132 \\
\hline R-squared & 0.080 & 0.080 & 0.078 & 0.222 & 0.222 & 0.217 \\
\hline Height or Log Height & Height & Log Height & Height & Height & Log Height & Height \\
\hline Age Controls & Age & Age & 5 Yr Age Group & Age & Age & 5 Yr Age Group \\
\hline Other Controls & No & No & No & Yes & Yes & Yes \\
\hline
\end{tabular}

Note: Each panel shows linear regression coefficients for height for the same outcome, using 6 different model specifications. The pooled sample of countries is used and stratified by sex. Very good or good self-reported health is a binary outcome indicating the respondent was in the top two self-reported health categories. No Difficulties with ADL or IADL is a binary variable indicating the respondent reported no difficulties with any of the 22 activities of daily living and instrumental activities of daily living. Standard errors account for clustering at the primary sampling unit (PSU) level. Other controls include country, ethnicity, and parental education. 
Table 3: The Association Between Stature and Later Life Health (Women)

\begin{tabular}{lcccccc}
\hline & Model 1 & Model 2 & Model 3 & Model 4 & Model 5 & Model 6 \\
OLS & OLS & OLS & OLS & OLS & $\begin{array}{c}\text { OLS } \\
\text { Height Coefficient }\end{array}$ \\
\cline { 2 - 7 } & $0.031^{* * *}$ & $4.776^{* * *}$ & $0.031^{* * *}$ & $0.018^{* * *}$ & $2.810^{* * *}$ & $0.019^{* * *}$ \\
& $(0.002)$ & $(0.329)$ & $(0.002)$ & $(0.002)$ & $(0.332)$ & $(0.002)$ \\
Observations & 17,046 & 17,046 & 16,518 & 17,032 & 17,032 & 16,518 \\
R-squared & 0.086 & 0.085 & 0.088 & 0.220 & 0.219 & 0.213 \\
\hline
\end{tabular}

\begin{tabular}{lcccccc} 
& \multicolumn{5}{c}{ Outcome: Lung Function (Women) } \\
\cline { 2 - 7 } Height Coefficient & $0.042^{* * *}$ & $6.410^{* * *}$ & $0.041^{* * *}$ & $0.028^{* * *}$ & $4.240^{* * *}$ & $0.028^{* * *}$ \\
& $(0.002)$ & $(0.272)$ & $(0.002)$ & $(0.001)$ & $(0.220)$ & $(0.001)$ \\
Observations & 16,516 & 16,516 & 16,150 & 16,506 & 16,506 & 16,150 \\
R-squared & 0.110 & 0.110 & 0.119 & 0.232 & 0.232 & 0.235 \\
\hline
\end{tabular}

\begin{tabular}{|c|c|c|c|c|c|c|}
\hline \multirow[b]{2}{*}{ Height Coefficient } & \multicolumn{6}{|c|}{ Outcome: Very Good or Good Self-Reported Health (Women) } \\
\hline & $\begin{array}{c}0.001 \\
(0.001)\end{array}$ & $\begin{array}{c}0.116 \\
(0.102)\end{array}$ & $\begin{array}{c}0.001 \\
(0.001)\end{array}$ & $\begin{array}{c}0.002^{* * *} \\
(0.001)\end{array}$ & $\begin{array}{c}0.352^{* * *} \\
(0.089)\end{array}$ & $\begin{array}{c}0.002^{* * *} \\
(0.001)\end{array}$ \\
\hline Observations & 18,542 & 18,542 & 17,942 & 18,527 & 18,527 & 17,942 \\
\hline R-squared & 0.026 & 0.026 & 0.022 & 0.074 & 0.074 & 0.066 \\
\hline \multirow[b]{2}{*}{ Height Coefficient } & \multicolumn{6}{|c|}{ Outcome: No Difficulties with ADL/IADL (Women) } \\
\hline & $\begin{array}{c}0.008^{* * *} \\
(0.001)\end{array}$ & $\begin{array}{c}1.245^{* * *} \\
(0.144)\end{array}$ & $\begin{array}{c}0.008^{* * *} \\
(0.001)\end{array}$ & $\begin{array}{c}0.003^{* * *} \\
(0.001)\end{array}$ & $\begin{array}{c}0.505^{* * *} \\
(0.116)\end{array}$ & $\begin{array}{c}0.004^{* * *} \\
(0.001)\end{array}$ \\
\hline Observations & 17,990 & 17,990 & 17,990 & 17,990 & 17,990 & 17,990 \\
\hline R-squared & 0.072 & 0.072 & 0.072 & 0.248 & 0.248 & 0.245 \\
\hline Height or Log Height & Height & Log Height & Height & Height & Log Height & Height \\
\hline Age Controls & Age & Age & 5 Yr Age Group & Age & Age & 5 Yr Age Group \\
\hline Other Controls & No & No & No & Yes & Yes & Yes \\
\hline
\end{tabular}

Note: Each panel shows linear regression coefficients for height for the same outcome, using 6 different model specifications. The pooled sample of countries is used and stratified by sex. Very good or good self-reported health is a binary outcome indicating the respondent was in the top two self-reported health categories. No Difficulties with ADL or IADL is a binary variable indicating the respondent reported no difficulties with any of the 22 activities of daily living and instrumental activities of daily living. Standard errors account for clustering at the primary sampling unit (PSU) level. Other controls include country, ethnicity, and parental education. 
The model can be summarised as follows:

$$
\begin{gathered}
\text { HealthOutcome }_{\text {igc }}=\text { Height }_{i g c} \beta+\text { Age }_{\text {igc }} \gamma+\text { ParentalEducation }_{\text {igc }} \theta+\text { Ethnicity }_{\text {igc }} \delta+\mu_{i g c} \\
g \in\{1,2\}, c \in\{0,1,2,3,4,5,6,7\}
\end{gathered}
$$

Where the health outcome for individual $i$, of $\operatorname{sex} g$, in country $c$, is a function of height, age, parental education, and ethnicity. $\mu$ is the corresponding error term. $\beta$ is therefore the main paramater of interest. In addition to stratifying by sex and the 6 countries in the SAGE data and one in LASI, I run a pooled specification for all countries $(c=0)$ which additionally controls for country fixed effects, resulting in 8 separate models for each sex. ${ }^{7}$ The results are summarised in figures 1 and 2 (Jann, 2013), which show the point estimate for each country along with $95 \%$ confidence intervals, which are adjusted for clustering at the PSU level. The full results are presented as tables A1-A8 in the appendix.

The coefficient estimates for $\beta$ are generally similar across countries, outcomes and sex. Most estimates are statistically different from 0, apart from the following: India (LASI) (lung function for men and women); Ghana (self-rated health for men and women, no difficulties with ADL and IADL for women); Mexico (self-rated health for men and women,no difficulties with ADL and IADL for women); India (SAGE) (self-rated health for women) and South Africa (no difficulties with ADL and IADL for women).

For self-rated health and no difficulties with ADL and IADL, the pooled estimate for men is 0.003, indicating that a $10 \mathrm{~cm}$ increase in height is associated with a 3 percentage point increase in the probability of reporting being in very good or good health, and a 3 percentage point increase in the probability of having no difficulties with ADL or IADL. For women, these estimates are 0.002 and 0.003 respectively. We can reject that coefficients are different from the pooled estimate for these outcomes in 5 cases (self-reported health for women in Russia, Mexico, self-reported health for men in India (LASI) and Ghana, no difficulties with ADL and IADL in Ghana for women).

For grip strength among men, the pooled estimate is 0.026 , indicating that a $10 \mathrm{~cm}$ increase in height is associated with roughly a quarter of a standard deviation increase in grip strength. For women, the equivalent coefficient is 0.018 . For lung function, the pooled estimate for both men and women is 0.028. For men, the grip strength coefficients range from 0.014 (Mexico) to 0.030 (China). We can reject the null hypothesis that the country-specific coefficient is equal to the pooled effect for Mexico only. There is a similar range for lung function, and in this case the coefficients for both India (LASI) (0.011) and China (0.035) are statistically different from the pooled sample.

For women, the grip strength coefficients range from 0.006 in Ghana to 0.024 in South Africa, and only the former can be distinguished statistically from the pooled estimate. For lung function, estimates for the coefficients range from 0.014 in India (LASI) to 0.035 in China, and the latter and India (SAGE) can be distinguished from the pooled coefficient.

\footnotetext{
${ }^{7}$ Apart from the models for no difficulties with ADL/IADL, which use the SAGE data only.
} 
Figure 1: Cross Country Comparisons of Height Associations (Self-Reported Health and No Difficulties with ADL/IADL)
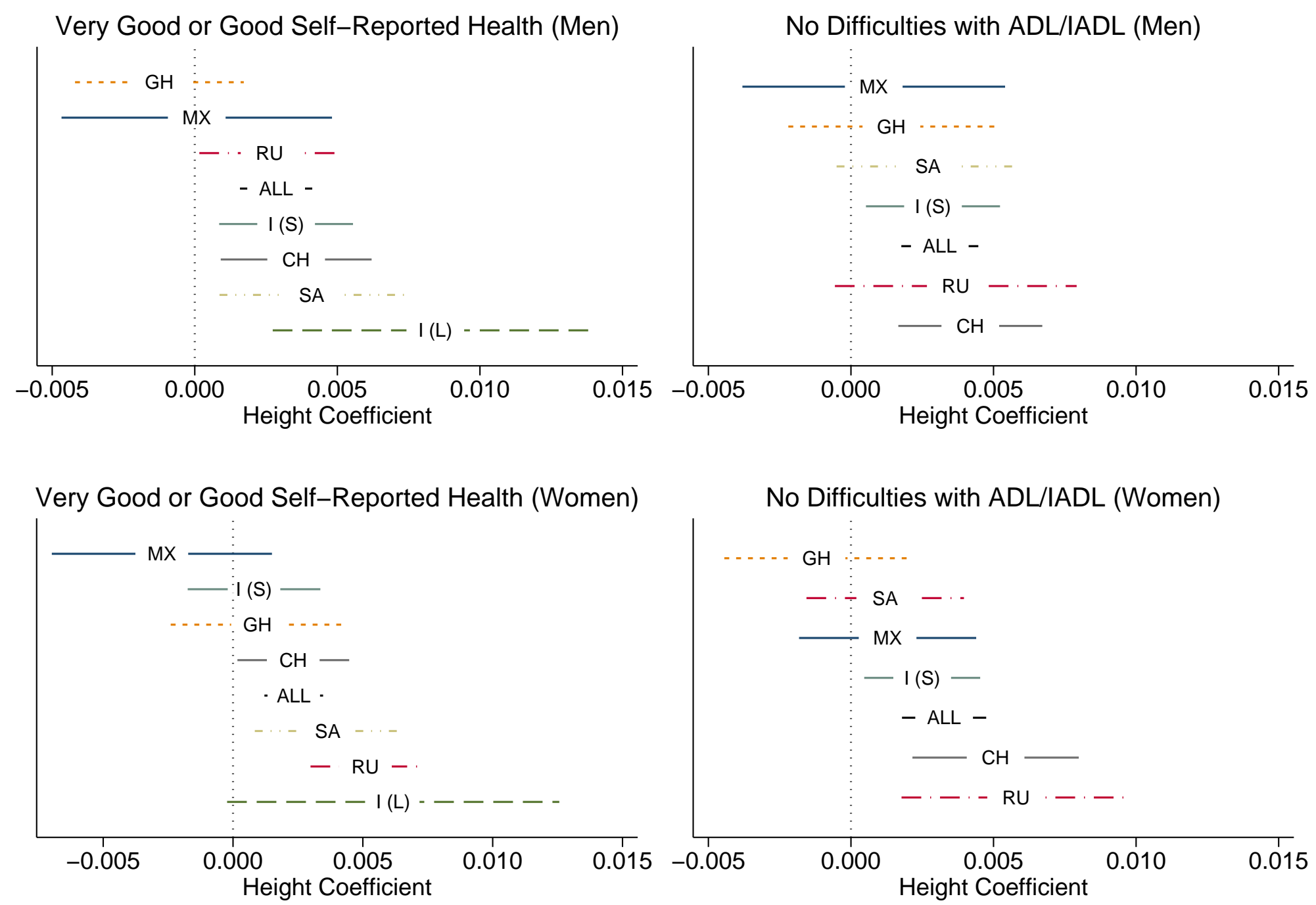

Note: Point estimates from a linear probability model for a $1 \mathrm{~cm}$ increase in height on the probability of the outcome occurring, using the model outlined in equation (1), stratified by country and sex are shown. The bars represent $95 \%$ confidence intervals. Standard errors account for clustering at the PSU level. Full estimates are shown in tables A1-A8 in the appendix. MX refers to Mexico, I (L) - India LASI, I (S) - India SAGE, RU - Russia, ALL - Pooled Sample, GH - Ghana, SA - South Africa, CH - China. The models for no difficulties with ADL and IADL are for SAGE only. Source: WHO SAGE wave1 and LASI pilot. 
Figure 2: Cross Country Comparisons of Height Associations (Grip Strength and Lung Function)
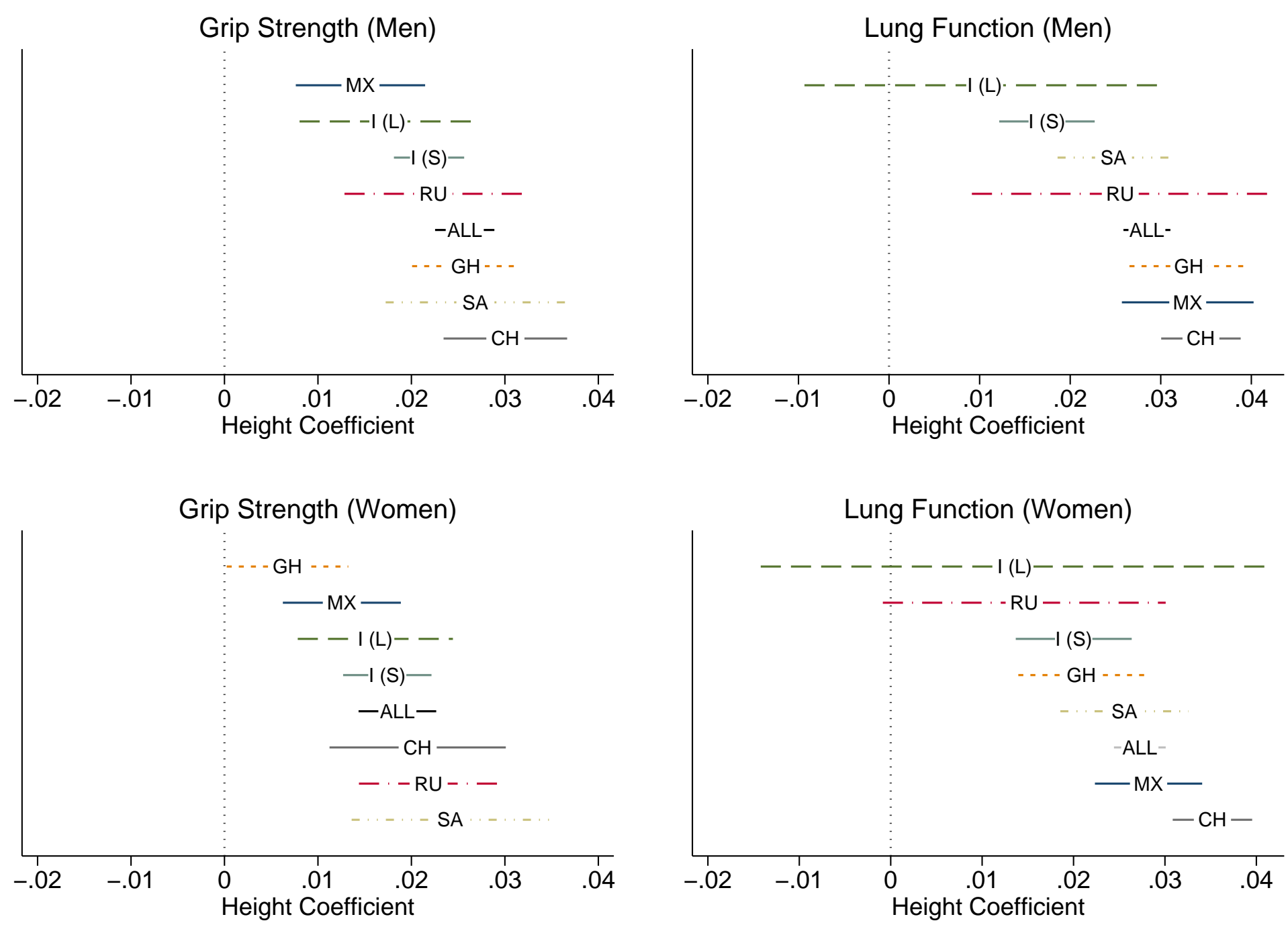

Note: Point estimates from a linear regression model for a $1 \mathrm{~cm}$ increase in height on the $\mathrm{Z}$ score for each outcome, using the model outlined in equation (1), stratified by country and sex are shown. The bars represent 95\% confidence intervals. Standard errors account for clustering at the PSU level. Full estimates are shown in tables A1-A8 in the appendix. MX refers to Mexico, I (L) - India LASI, I (S) - India SAGE, RU - Russia, ALL - Pooled Sample, GH - Ghana, SA - South Africa, CH - China. Source: WHO SAGE wave1 and LASI pilot. 
Overall, these results indicate a correlation between height and the health outcomes which is relatively consistent. Comparing countries, the coefficients are broadly similar, although the country rankings do depend on the outcome. For example, there is no height association for self-rated health and no difficulties with ADL and IADL in Mexico and Ghana. Comparing India (SAGE) and India (LASI), standard errors are much higher for the latter. For example, the standard error associated with the point estimate for lung function among women in SAGE is 0.003, while it is 0.014 for LASI. It would be interesting to examine whether these differences persist when the data from the first full round of LASI become available.

\section{Comparisons and Decomposition based on Concentration In- dices}

When comparing estimates across heterogeneous groups, analysis based on mean effects could mask important differences. Even given the same regression parameters in two particular countries, the actual distributions of a particular outcome could be substantially different. Two advantages of using the inequality framework outlined in detail below is that this approach can be used to investigate the extent of inequality in the entire distribution of the outcome of interest, and additionally allows for the decomposition of the inequality in grip strength (or equivalent health measure) into its constituent parts based on observed characteristics. In the following section, I present the results for grip strength among men using concentration curves and concentration indices. Results for women and lung function are shown in the appendix.

\subsection{Concentration Curves}

I begin by graphing the relevant concentration curves for grip strength, defined as the share of the outcome accounted for by the cumulative proportion of respondents ranked according to a measure of socioeconomic status (Kakwani et al., 1997). In this case it is the shares of the health variable (grip strength) plotted against quantiles of height for men. If the given outcome was shared equally among the population, the concentration curve would lie along the 45 degree line (the line of equality). If instead the concentration curve lies below this line, this indicates that the health outcome accrues disproportionately to taller individuals (who likely had more favourable early life conditions). The further the concentration curve lies below the line of equality, the greater the amount of inequality in the population.

As discussed above, height is often used as a proxy for early life conditions in the literature. However, the same limitations to the use of height apply as in the regression framework. In particular, I am not able to distinguish between height-grip strength associations which are directly due to early life conditions, or those due to other indirect pathways (such as size effects). Nevertheless, the consistent association between height and all health outcomes examined in this paper in the previous section suggest that this relationship reflects a meaningful health advantage for taller respondents. In addition, it is not clear that ranking respondents according to their height reflects the ranking that would be obtained using an alternative measure of living standards in early life. If it were available, future research would ideally use another measure of living conditions in place of stature, such as household income during childhood. 
Figure 3: Concentration Curves for Grip Strength (Men)
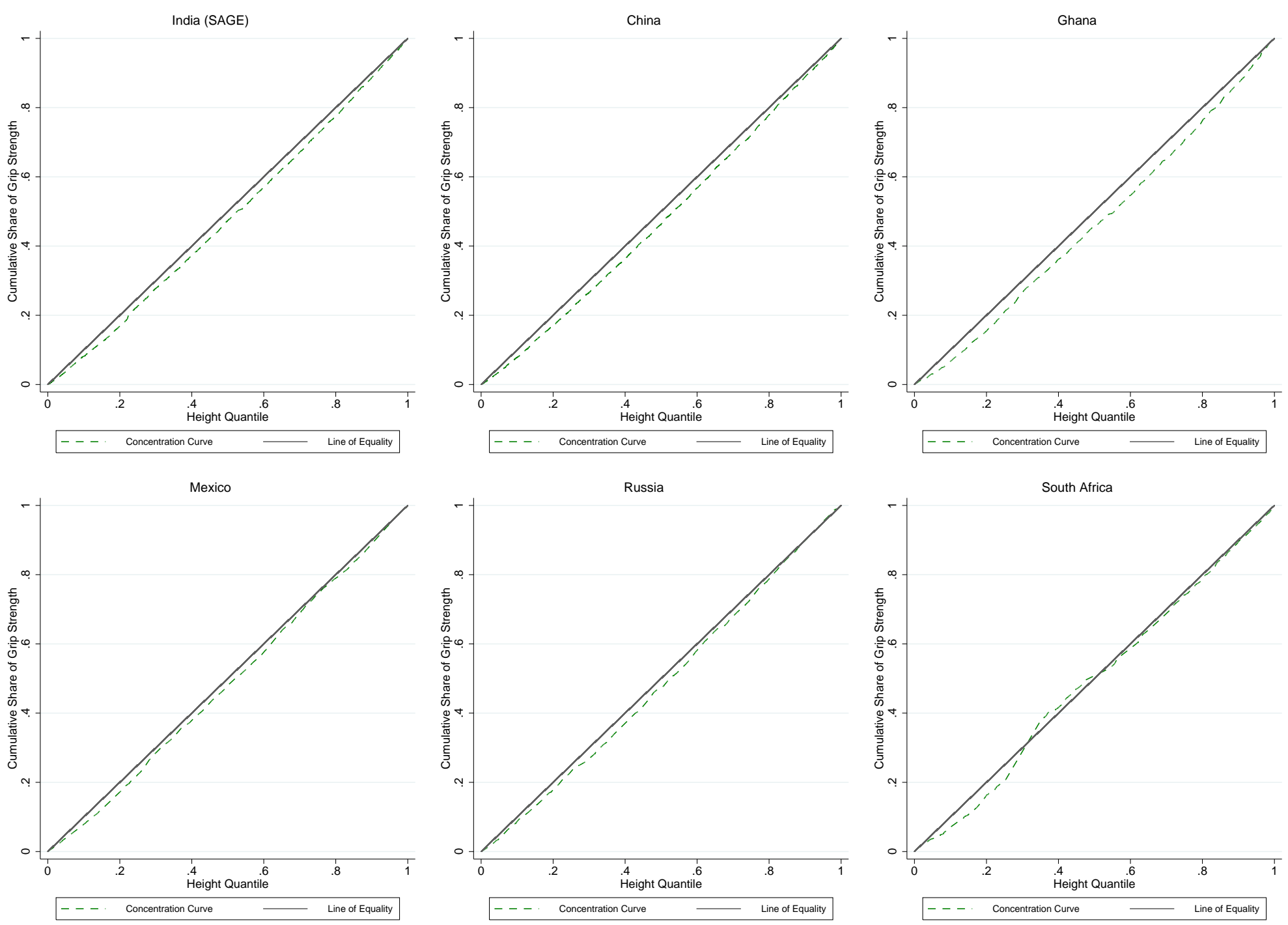

Note: Concentration curves for grip strength and height among men are shown for each country. Other outcomes are presented as figures A4-A6 in the appendix. Samples are weighted. Source: WHO SAGE wave1. 
Figure 3 presents the results of this analysis for each country in the SAGE data. In general, the concentration curves lie consistently under the 45 degree line. An exception is South Africa, where inequality is concentrated at the lower end of the height distribution. This information is also summarised in table A10 in the appendix, which presents the cumulative proportion of the health outcome accruing to the cumulative height distribution for each country. This analysis provides a useful description of inequality across countries. For example, for men and grip strength in India, the shortest $20 \%$ of individuals account for $16.90 \%$ of the grip strength score (where an equal distribution would be 20\%). At the first quintile India compares most favourably to Russia, where the shortest $20 \%$ of individuals account for only $14.58 \%$ of the grip strength score.

Having established the presence of a degree of inequality in these outcomes as measured by stature, the next section establishes the magnitude of these effects. It is possible to characterise the extent of inequality more formally using the concentration index, a measure encompassing the full distribution, and not just a particular quantile. The concentration index can also be decomposed into the factors which contribute to this inequality.

\subsection{Concentration Indices}

The overall extent of inequality can be measured formally by taking the distance from the concentration curve to the line of equality at each point in the distribution. This summary measure, the concentration index, is obtained by integrating over the area under the curve:

$$
C=1-2 \int_{0}^{1} L_{h}(p) d p
$$

Where $\mathrm{C}$, the concentration index is double the area between the concentration curve $\left(L_{h}\right)$ and the line of equality, and is bounded in the range \pm 1 . Similar to the interpretation of the position of the concentration curve itself, a positive value indicates that the disadvantaged receive a disproportionately greater share of the outcome, while a negative concentration index indicates that the less well-off receive disproportionately less than expected. The greater the magnitude of the concentration index (in absolute value), the greater the degree of inequality.

The concentration indices for each of the concentration curves presented in figure 3 (and their confidence intervals, which are calculated as per Kakwani et al. (1997), and adjusted for clustering at the PSU level), are shown in table 4. For men, height-related inequality is largest in Ghana, with a concentration index of $7.2 \%$. The levels in the other cases are smaller; however the concentration index in each country is significantly different from a concentration index of 0 apart from South Africa. The confidence intervals mainly overlap. Results for the other outcomes are shown in table A9 in the appendix, and are similar to those for grip strength among men, ranging from $0.6 \%$ for lung function in Russian women to $8.9 \%$ for grip strength among women in South Africa. Comparing the country rankings for height associations derived from the regression analysis to those in table 4 indicates that there does not appear to be a strong correlation between the two. 
Table 4: Grip Strength Concentration Index by Country (Men)

\begin{tabular}{|c|c|c|c|c|c|c|}
\hline India & LASI & China & $\begin{array}{c}\text { Men } \\
\text { Ghana }\end{array}$ & Mexico & Russia & South Africa \\
\hline $\begin{array}{c}0.043^{* * *} \\
(0.025-0.062)\end{array}$ & $\begin{array}{c}0.066^{* * *} \\
(0.041-0.090)\end{array}$ & $\begin{array}{c}0.047^{* * *} \\
(0.033-0.062)\end{array}$ & $\begin{array}{c}0.072^{* * *} \\
(0.044-0.101)\end{array}$ & $\begin{array}{c}0.033^{* * *} \\
(0.012-0.054)\end{array}$ & $\begin{array}{c}0.039 * * * \\
(0.020-0.059)\end{array}$ & $\begin{array}{c}0.019 \\
(-0.039-0.078)\end{array}$ \\
\hline
\end{tabular}

Note: Concentration indices for grip strength and height among men are shown. Samples are weighted and standard errors account for clustering at the PSU level.

\subsection{Decomposition of the Concentration Index}

Wagstaff et al. (2003) show that the concentration index can also be defined in terms of a regression model $\left(y=\beta_{k} x_{k}+e\right)$, with outcome $y, x_{k}$ explanatory variables, and their corresponding concentration indices $C_{k}$, the concentration index for variable $k$.

Then:

$$
C=\sum_{k=1}^{K}\left(\frac{\beta_{k} \bar{x}_{k}}{\bar{y}}\right) C_{k}+G C_{e} / \bar{y}
$$

Where $G C_{e}$ is the generalised concentration curve for the error term (Wagstaff et al., 1991). The concentration curve for a particular outcome then depends on the concentration curves of the explanatory variables in the model, with each weighted by the elasticity of the outcome with respect to that particular explanatory variable (Wagstaff et al., 2003). Therefore, it is possible to decompose a concentration index into the contributions made by a set of other factors which affect the outcome of interest. This includes factors for which there is, and for which there is not, an equivalent gradient in socioeconomic status. For example, the distribution of grip strength with respect to maternal education could be highly unequal, but if maternal education and height are unrelated then maternal education cannot explain the height gradient in grip strength.

The results of this decomposition analysis for grip strength, which shows the contribution (expressed as a proportion) of each variable to the concentration index among men, is presented in table 5 . I use the same variables present in the regression analysis outlined in equation (1), namely age, 
parental education, and ethnicity. ${ }^{8}$ A positive contribution indicates that the variable acts to increase the height related inequality gradient for that particular outcome. As with the regression analysis, the only consistent contributor to the height gradient in these health outcomes (apart from height itself) is age (or equivalently cohort in these cross sectional data), although the size of the contribution varies. For example, for grip strength and men a combination of age and cohort effects contribute $39.3 \%$ to the height gradient in Mexico, compared to only $8 \%$ in South Africa. The observed factors explain a high proportion of the gradient. A limitation of this analysis with these data is the lack of other variables, such as household income at birth, which are predetermined and could potentially contribute to explaining the observed relationship between height and the health outcomes.

Table 5: Decomposition for Grip Strength (Men) Contribution to Concentration Index (Expressed as a Proportion)

\begin{tabular}{lccccccc}
\hline Variable & India & LASI & China & Ghana & Mexico & Russia & South Africa \\
\hline Age & 0.233 & 0.184 & 0.301 & 0.100 & 0.393 & 0.123 & 0.080 \\
Height & 0.838 & 0.628 & 0.745 & 0.842 & 0.691 & 0.880 & 1.106 \\
Mother Had no Education & -0.020 & -0.004 & -0.001 & 0.003 & 0.044 & -0.001 & -0.464 \\
Mother's Education Missing & 0.010 & & 0.002 & -0.005 & 0.037 & 0.022 & 0.264 \\
Father Had no Education & -0.011 & 0.011 & 0.015 & 0.004 & -0.115 & -0.018 & -0.036 \\
Father's Education Missing & -0.004 & & -0.002 & 0.014 & -0.048 & 0.003 & -0.019 \\
Total Ethnic & -0.010 & 0.210 & -0.015 & -0.016 & -0.015 & -0.002 & 0.185 \\
Total & 1.036 & 1.029 & 1.045 & 0.942 & 0.987 & 1.007 & 1.116 \\
Residual & -0.036 & -0.029 & -0.045 & 0.058 & 0.013 & -0.007 & -0.116 \\
\hline
\end{tabular}

Note: Table shows a decomposition analysis for the concentration index based on equation (3). For each country, the contribution to the concentration index is shown. The ethnicity coefficient represents the combined effect for all ethnicity categories. Samples are weighted.

\footnotetext{
${ }^{8} \mathrm{~A}$ series of dummy variables for ethnicity are included in the analysis; the sum of their coefficients is shown in the table.
} 


\section{Conclusions}

This paper compares the relationship between height and 4 health measures (self-rated health, no difficulties with ADL and IADL, grip strength, and lung function) across 6 lower and middle income countries. I find a consistent association of stature with later life health outcomes. Given that height is routinely used as a proxy for early life conditions (Akachi and Canning, 2010; Case and Paxson, 2008, 2010; Lee and Smith, 2014; Smith et al., 2012), this indicates that improvements in childhood circumstance could be associated with health improvements in later life for the adults affected (Abbott et al., 1998), although further analysis is required to establish a causal link. These results are broadly in line with the existing literature on developed countries, which have found that early life conditions are correlated with a variety of different outcomes (Currie and Vogl, 2013; McEniry, 2013). The magnitude of the associations presented in this paper appears meaningful. For example, using the pooled estimate of 0.026 from the regression analysis of height on grip strength, if Mexico were to increase average height by $7 \mathrm{~cm}$ from $157 \mathrm{~cm}$ to $164 \mathrm{~cm}$ to match average height in Russia (the tallest country in the sample), the implied improvement in the average grip strength score in Mexico is 2.4 points, increasing from 23 to 25.4.

This represents almost a $50 \%$ reduction in the gap between the grip strength score in the two countries (Russia has a mean grip strength score of 29). The high degree of stunting in many low and middle income countries (Black et al., 2008) implies that there may be substantial scope for increasing height through advances in nutrition and improvements in disease environment, and results which link the health measures in this paper to mortality and other outcomes (Cook et al., 1995; Klein et al., 2005; Mannino et al., 2003; Mossey and Shapiro, 1982; Scott et al., 1997; Rantanen et al., 1999; Sharp et al., 1997) suggest that this may be accompanied by health benefits in later life for the cohorts which experience these improvements in childhood.

A second contribution of this analysis is the adoption of a methodology used in the inequality literature to compare the height related gradient in health outcomes in each country. This allows the comparison of associations which are based on distributions as opposed to just mean differences. Results indicate that inequality is greatest for male grip strength in Ghana at $7.2 \%$. In terms of previous research using data from ageing studies, this magnitude compares to education and wealth related concentration indices of between $-19 \%$ and $+21 \%$ for a variety of self-reported diagnoses and standardized measures of disease in India (Vellakkal et al., 2013). In this paper, the country rankings based on the height-health association differ according to whether the inequality measure or regression coefficient is used; however, overall the associations are reasonably stable. Relatively small sample sizes and correspondingly wide confidence intervals mean that it is difficult to reject that the country coefficients are the same as the pooled sample estimate in most cases. Further data would help to establish the extent to which these associations differ across countries.

There are a number of important limitations to this study. Firstly, the results presented here are associational, and do not necessarily imply causal relationships. Secondly, the use of height in the literature partly reflects the lack of additional measures of childhood circumstance. While height is widely collected in surveys, it is an imperfect proxy for initial environment and is associated with many other factors, including genetics and size, and therefore isolating the particular mechanisms linking height to later outcomes is problematic. Measurement error could reduce the estimates towards the null and inflate standard errors. Additionally, an association between height and a 
health measure could reflect a size effect rather than a meaningful health effect. Future research with data such as that from CHARLS and LASI with additional measures on initial conditions should prove useful in further investigating the mechanisms through which early life environment is related to later outcomes. In this paper I have mainly focused on health outcomes related to physical frailty, however it would be interesting to consider other types of outcomes, such as cognition. If more life course information becomes available, particularly on a factor such as family income during childhood, the concentration index approach could provide meaningful insights into the extent to which health is distributed unequally according to early life conditions across countries. In addition, the use of the decomposition approach could allow researchers to evaluate the relative contribution of different aspects of early environment, such as socioeconomic status, education, and health.

Finally, the roll-out of new surveys collecting comparable data on population ageing at the micro level will allow researchers to conduct more cross country analyses with the goal of addressing some of the questions outlined in the introduction, such as the extent to which the lasting impact of early life conditions can be mitigated. Explaining why countries show stronger associations for some outcomes than for others is an important direction for future research, and with additional countries, and a broader set of regions, the emergence of new micro datasets in the field of ageing should make it be possible to examine how socioeconomic and institutional context interact with the association of height and health documented in this analysis. 


\section{References}

R. D. Abbott, L. R. White, G. W. Ross, H. Petrovitch, K. H. Masaki, D. A. Snowdon, and J. D. Curb. Height as a marker of childhood development and late-life cognitive function: the Honolulu Asia aging study. Pediatrics, 102 (3):602-609, 1998. ISSN 0031-4005.

Y. Akachi and D. Canning. Health trends in Sub-Saharan Africa: Conflicting evidence from infant mortality rates and adult heights. Economics and Human Biology, 8(2):273-288, 2010. ISSN 1570677X.

D. Almond and J. Currie. Chapter 15 - human capital development before age five. In O. Ashenfelter and D. Card, editors, Handbook of Labor Economics, volume Volume 4, Part B, pages 1315-1486. Elsevier, 2011a. ISBN 15734463. URL http://www.sciencedirect.com/science/article/pii/S0169721811024130.

D. Almond and J. Currie. Killing me softly: The fetal origins hypothesis. Journal Of Economic Perspectives, 25(3): 153-172, 2011b. ISSN 08953309. URL https://www.aeaweb.org/articles.php?doi=10.1257/jep.25.3.153.

P. Arokiasamy, D. Bloom, J. Lee, K. Feeney, and M. Ozolins. Longitudinal aging study in India: vision, design, implementation, and some early results. In J. P. Smith and M. Majmundar, editors, Aging in Asia: findings from new and emerging data initiatives. National Academies Press, 2012.

J. Banks and J. P. Smith. International comparisons in health economics: evidence from aging studies. Annual review of economics, 4:57, 2012.

J. Banks, M. Marmot, Z. Oldfield, and J. P. Smith. Disease and disadvantage in the United States and in England. JAMA: the journal of the American Medical Association, 295(17):2037-2045, 2006. ISSN 0098-7484.

J. Banks, Z. Oldfield, and J. P. Smith. Childhood health and differences in late-life health outcomes between England and the United States. In Investigations in the Economics of Aging, pages 321-339. University of Chicago Press, 2011.

D. J. Barker. Fetal origins of coronary heart disease. BMJ, 311(6998):171-174, 1995. ISSN 0959-8138.

S. Basu and C. Millett. Social epidemiology of hypertension in middle-income countries determinants of prevalence, diagnosis, treatment, and control in the WHO SAGE study. Hypertension, 62(1):18-26, 2013. ISSN 0194-911X.

J. R. Behrman and A. B. Deolalikar. Health and nutrition. Handbook of Development Economics, 1:631-711, 1988.

H. Beltrán-Sánchez, E. M. Crimmins, G. M. Teruel, and D. Thomas. Links between childhood and adult social circumstances and obesity and hypertension in the Mexican population. Journal of aging and health, 23(7):11411165, 2011. ISSN 0898-2643.

R. E. Black, L. H. Allen, Z. A. Bhutta, L. E. Caulfield, M. De Onis, M. Ezzati, C. Mathers, and J. Rivera. Maternal and child undernutrition: global and regional exposures and health consequences. The Lancet, 371(9608):243-260, 2008. ISSN 0140-6736.

D. E. Bloom, E. Cafiero, E. Jan-Llopis, S. Abrahams-Gessel, L. R. Bloom, S. Fathima, A. B. Feigl, T. Gaziano, A. Hamandi, and M. Mowafi. The Global Economic Burden of Noncommunicable Diseases. World Economic Forum, Geneva, 2011.

D. E. Bloom, P. Hu, P. Arokiasamy, A. Risbud, T. Sekher, S. Mohanty, V. Kale, J. O'Brien, S. Chien, and J. Lee. Longitudinal aging study in India: Biomarker data documentation. PGDA Working Paper No. 114, 2014.

P. Böckerman and J. Vainiomäki. Stature and life-time labor market outcomes: Accounting for unobserved differences. Labour Economics, 24:86-96, 2013.

C. Bozzoli, A. Deaton, and C. Quintana-Domeque. Adult height and childhood disease. Demography, 46(4):647-669, Nov. 2009. ISSN 0070-3370. doi: 10.1353/dem.0.0079. URL http://dx.doi.org/10.1353/dem.0.0079.

A. Case and C. Paxson. Stature and status: Height, ability, and labor market outcomes. Journal of Political Economy, 116(3), 2008. 
A. Case and C. Paxson. Causes and consequences of early-life health. Demography, 47(1):S65-S85, 2010. ISSN 0070-3370.

S. Chatterji, P. Kowal, C. Mathers, N. Naidoo, E. Verdes, J. P. Smith, and R. Suzman. The health of aging populations in China and India. Health Affairs, 27(4):1052-1063, 2008. ISSN 0278-2715.

N. R. Cook, M. S. Albert, L. F. Berkman, D. Blazer, J. O. Taylor, and C. H. Hennekens. Interrelationships of peak expiratory flow rate with physical and cognitive function in the elderly: MacArthur foundation studies of aging. The Journals of Gerontology Series A: Biological Sciences and Medical Sciences, 50(6):M317-M323, 1995. ISSN 1079-5006.

E. M. Crimmins and C. E. Finch. Infection, inflammation, height, and longevity. Proceedings of the National Academy of Sciences of the United States of America, 103(2):498-503, 2006. ISSN 0027-8424.

J. Currie and T. Vogl. Early-life health and adult circumstance in developing countries. Annual Review of Economics, 5:1-36, 2013. ISSN 1941-1383.

A. Deaton. The analysis of household surveys: a microeconometric approach to development policy. World Bank Publications, 1997. ISBN 0801852544.

A. Deaton. Height, health, and development. Proceedings of the National Academy of Sciences, 104(33):13232-13237, 2007. ISSN 0027-8424.

D. S. DeGraff and R. Wong. Modeling old-age wealth with endogenous early-life outcomes: The case of Mexico. The Journal of the Economics of Ageing, 3:58-70, 2014. ISSN 2212-828X. doi: 10.1016/j.jeoa.2013.11.002. URL http://www.sciencedirect.com/science/article/pii/S2212828X13000194.

E. Doherty, B. Walsh, and C. ONeill. Decomposing socioeconomic inequality in child vaccination: Results from Ireland. Vaccine, 32(27):3438-3444, 2014.

G. L. Drevenstedt, E. M. Crimmins, S. Vasunilashorn, and C. E. Finch. The rise and fall of excess male infant mortality. Proceedings of the National Academy of Sciences, 105(13):5016-5021, 2008. ISSN 0027-8424.

A. Fernihough and M. E. McGovern. Physical stature decline decline and the health status of the elderly population in England. Economics and Human Biology, (Forthcoming), 2014. doi: 10.1016/j.ehb.2013.12.010. URL http: //www.sciencedirect.com/science/article/pii/S1570677X14000033.

R. Fogel. The escape from hunger and premature death, 1700-2100: Europe, America, and the Third World, volume 38. Cambridge University Press, 2004. ISBN 0521004888.

J.-P. Habicht, C. Yarbrough, R. Martorell, R. Malina, and R. Klein. Height and weight standards for preschool children: how relevant are ethnic differences in growth potential? The Lancet, 303(7858):611-615, 1974. ISSN 0140-6736.

K. Harttgen, P. Kowal, H. Strulik, S. Chatterji, and S. Vollmer. Patterns of frailty in older adults: comparing results from higher and lower income countries using the survey of health, ageing and retirement in Europe (SHARE) and the study on global AGEing and adult health (SAGE). PloS one, 8(10):e75847, 2013. ISSN 1932-6203.

W. Huang, X. Lei, G. Ridder, J. Strauss, and Y. Zhao. Health, height, height shrinkage, and SES at older ages: Evidence from China. American Economic Journal: Applied Economics, 5(2):86-121, 2013. doi: 10.1257/app.5.2. 86. URL http://www. aeaweb.org/articles.php?doi=10.1257/app.5.2.86.

E. Hudson, I. Mosca, and D. Madden. A formal investigation of inequalities in health behaviours after age 50 on the island of Ireland. Economic and Social Review, Forthcoming, 2014.

B. Jann. Plotting regression coefficients and other estimates in Stata. University of Bern Social Sciences Working Papers, 2013.

N. Kakwani, A. Wagstaff, and E. Van Doorslaer. Socioeconomic inequalities in health: measurement, computation, and statistical inference. Journal of econometrics, 77(1):87-103, 1997. ISSN 0304-4076. 
A. Kapteyn. What can we learn from (and about) global aging? Demography, 47(1):S191-S209, Mar. 2010. ISSN 0070-3370. doi: 10.1353/dem.2010.0006. URL http://dx.doi.org/10.1353/dem.2010.0006.

B. E. Klein, R. Klein, M. D. Knudtson, and K. E. Lee. Frailty, morbidity and survival. Archives of Gerontology and Geriatrics, 41(2):141-149, Sept. 2005. ISSN 0167-4943. doi: 10.1016/j.archger.2005.01.002. URL http: //www.sciencedirect.com/science/article/pii/S0167494305000154.

P. Kowal, S. Chatterji, N. Naidoo, R. Biritwum, W. Fan, R. L. Ridaura, T. Maximova, P. Arokiasamy, N. PhaswanaMafuya, and S. Williams. Data resource profile: the world health organization study on global AGEing and adult health (SAGE). International Journal of Epidemiology, 41(6):1639-1649, 2012. ISSN 0300-5771.

D. LaFave and D. Thomas. Height and cognition at work: labor market performance in a low income setting. Working Paper, Department of Economics, Colby College, USA, 2013.

R. Layte and A. Nolan. Income-related inequity in the use of GP services by children: a comparison of Ireland and Scotland. The European Journal of Health Economics, pages 1-18, 2014. ISSN 1618-7598.

J. Lee and J. P. Smith. Regional disparities in adult height, educational attainment, and late-life cognition: Findings from the longitudinal aging study in India (LASI). The Journal of the Economics of Ageing, Forthcoming, 2014. ISSN 2212-828X. doi: 10.1016/j.jeoa.2014.02.002. URL http://www.sciencedirect.com/science/article/pii/ S2212828X14000036.

D. Madden. The relationship between low birth weight and socioeconomic status in Ireland. Journal of Biosocial Science, pages 1-18, 2013a. ISSN 1469-7599. doi: 10.1017/S0021932013000187.

D. Madden. The socio-economic gradient of obesity in Ireland. The Economic and Social Review, 44(2):181-196, 2013b.

D. M. Mannino, A. S. Buist, T. L. Petty, P. L. Enright, and S. C. Redd. Lung function and mortality in the United States: data from the first National Health and Nutrition Examination Survey follow up study. Thorax, 58(5): 388-393, May 2003. doi: 10.1136/thorax.58.5.388. URL http://thorax.bmj.com/content/58/5/388.abstract.

M. McEniry. Early-life conditions and older adult health in low-and middle-income countries: a review. Journal of developmental origins of health and disease, 1(1):1-20, 2013. ISSN 2040-1752.

M. McEniry and A. Palloni. Early life exposures and the occurrence and timing of heart disease among the older adult Puerto Rican population. Demography, 47(1):23-43, 2010.

M. E. McGovern. How much does birth weight matter for child health in developing countries? Estimates from siblings and twins. Harvard University OpenScholar Working Paper 143921, 2014. URL http://ideas.repec. org/p/qsh/wpaper/143921.html.

E. Meijer, A. Kapteyn, and T. Andreyeva. Internationally comparable health indices. Health economics, 20(5): 600-619, 2011. ISSN 1099-1050.

J. M. Mossey and E. Shapiro. Self-rated health: a predictor of mortality among the elderly. American journal of public health, 72(8):800-808, 1982. ISSN 0090-0036.

N. Naidoo, S. Abdullah, A. Bawah, F. Binka, N. T. Chuc, C. Debpuur, A. Ezeh, F. X. Gomez-Olive, M. Hakimi, and H. Van Minh. Ageing and adult health status in eight lower-income countries: the INDEPTH WHO-SAGE collaboration. Global Health Action, page 11, 2010.

O. O'Donnell, E. van Doorslaer, A. Wagstaff, and M. Lindelow. Analyzing health equity using household survey data: A guide to techniques and their implementation. World Bank Publications, 2008.

T. Rantanen, J. M. Guralnik, D. Foley, K. Masaki, S. Leveille, J. D. Curb, and L. White. Midlife hand grip strength as a predictor of old age disability. JAMA: the journal of the American Medical Association, 281(6):558-560, 1999. ISSN 0098-7484. 
J. A. Salomon, A. Tandon, and C. J. Murray. Comparability of self rated health: cross sectional multi-country survey using anchoring vignettes. BMJ, 328(7434):258, 2004. ISSN 0959-8138.

W. K. Scott, C. A. Macera, C. B. Cornman, and P. A. Sharpe. Functional health status as a predictor of mortality in men and women over 65. Journal of clinical epidemiology, 50(3):291-296, 1997. ISSN 0895-4356.

D. S. Sharp, C. M. Burchfiel, J. D. Curb, B. L. Rodriguez, and P. L. Enright. The synergy of low lung function and low body mass index predicting all-cause mortality among older japanese-american men. Journal of the American Geriatrics Society, 45(12):1464, 1997. ISSN 0002-8614.

J. P. Smith. Reconstructing childhood health histories. Demography, 46(2):387-403, 2009. ISSN $0070-3370$.

J. P. Smith, Y. Shen, J. Strauss, Y. Zhe, and Y. Zhao. The effects of childhood health on adult health and SES in China. Economic development and cultural change, 61(1):127, 2012.

K. Sohn. The height premium in Indonesia. Economics \& Human Biology, Forthcoming, 2014. ISSN 1570-677X.

R. H. Steckel. Biological measures of the standard of living. The Journal of Economic Perspectives, 22(1):129-152, 2008. ISSN 0895-3309.

R. H. Steckel. Heights and human welfare: Recent developments and new directions. Explorations in Economic History, 46(1):1-23, 2009. ISSN 0014-4983. doi: 10.1016/j.eeh.2008.12.001. URL http://www.sciencedirect. $\mathrm{com} / \mathrm{science/article/pii/S0014498308000442.}$

J. Strauss and D. Thomas. Health, nutrition, and economic development. Journal of economic literature, 36(2): 766-817, 1998. ISSN 0022-0515.

H. Syddall, C. Cooper, F. Martin, R. Briggs, and A. Aihie Sayer. Is grip strength a useful single marker of frailty? Age and Ageing, 32(6):650-656, Nov. 2003. doi: 10.1093/ageing/afg111. URL http://ageing.oxfordjournals . org/content/32/6/650. abstract.

G. J. Van den Berg, M. Lindeboom, and M. Lopez. Inequality in individual mortality and economic conditions earlier in life. Social Science \& Medicine, 69(9):1360-1367, 2009. ISSN 0277-9536.

Doorslaer, E. van and Koolman, X. Explaining the differences in income related health inequalities across European countries. Health economics, 13(7):609-628, 2004. ISSN 1099-1050.

S. Vellakkal, S. Subramanian, C. Millett, S. Basu, D. Stuckler, and S. Ebrahim. Socioeconomic inequalities in noncommunicable diseases prevalence in india: disparities between self-reported diagnoses and standardized measures. PloS one, 8(7):e68219, 2013.

T. S. Vogl. Height, skills, and labor market outcomes in Mexico. Journal of Development Economics, 107:84-96, 2014. ISSN 0304-3878.

A. Wagstaff, P. Paci, and E. van Doorslaer. On the measurement of inequalities in health. Social science $\mathscr{E}$ medicine, 33(5):545-557, 1991. ISSN 0277-9536.

A. Wagstaff, E. van Doorslaer, and N. Watanabe. On decomposing the causes of health sector inequalities with an application to malnutrition inequalities in Vietnam. Journal of econometrics, 112(1):207-223, 2003. ISSN 0304-4076.

S. P. Walker, T. D. Wachs, J. Meeks Gardner, B. Lozoff, G. A. Wasserman, E. Pollitt, and J. A. Carter. Child development: risk factors for adverse outcomes in developing countries. The Lancet, 369(9556):145-157, 2007. ISSN 0140-6736.

B. Walsh and J. Cullinan. Decomposing socioeconomic inequalities in childhood obesity: Evidence from Ireland. Economics \& Human Biology, (Forthcoming), 2014. ISSN 1570-677X. doi: 10.1016/j.ehb.2014.01.003. URL http://www.sciencedirect.com/science/article/pii/S1570677X14000264.

Y. Zhao, Y. Hu, J. P. Smith, J. Strauss, and G. Yang. Cohort profile: The China health and retirement longitudinal study (CHARLS). International Journal of Epidemiology, Dec. 2012. doi: 10.1093/ije/dys203. URL http: //ije.oxfordjournals.org/content/early/2012/12/12/ije.dys203. abstract. 


\section{Appendix}

Figure A1: Distribution of Height by Country

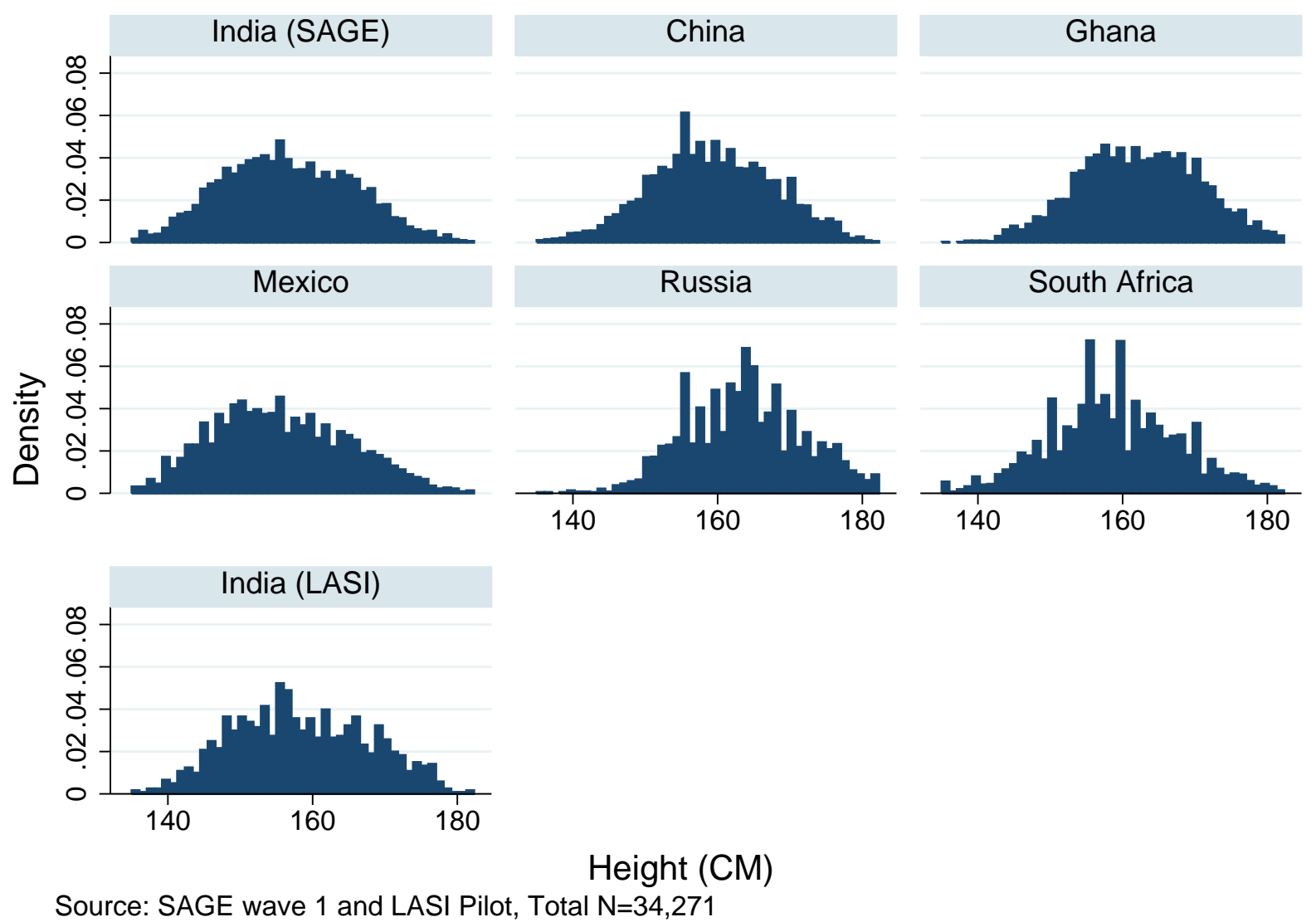

Note: The analysis sample is restricted to those over the age of 45, and those between the 1st and 99th percentiles of the height distribution. Samples are weighted to be nationally representative. 
Figure A2: Distribution of Grip Strength by Country

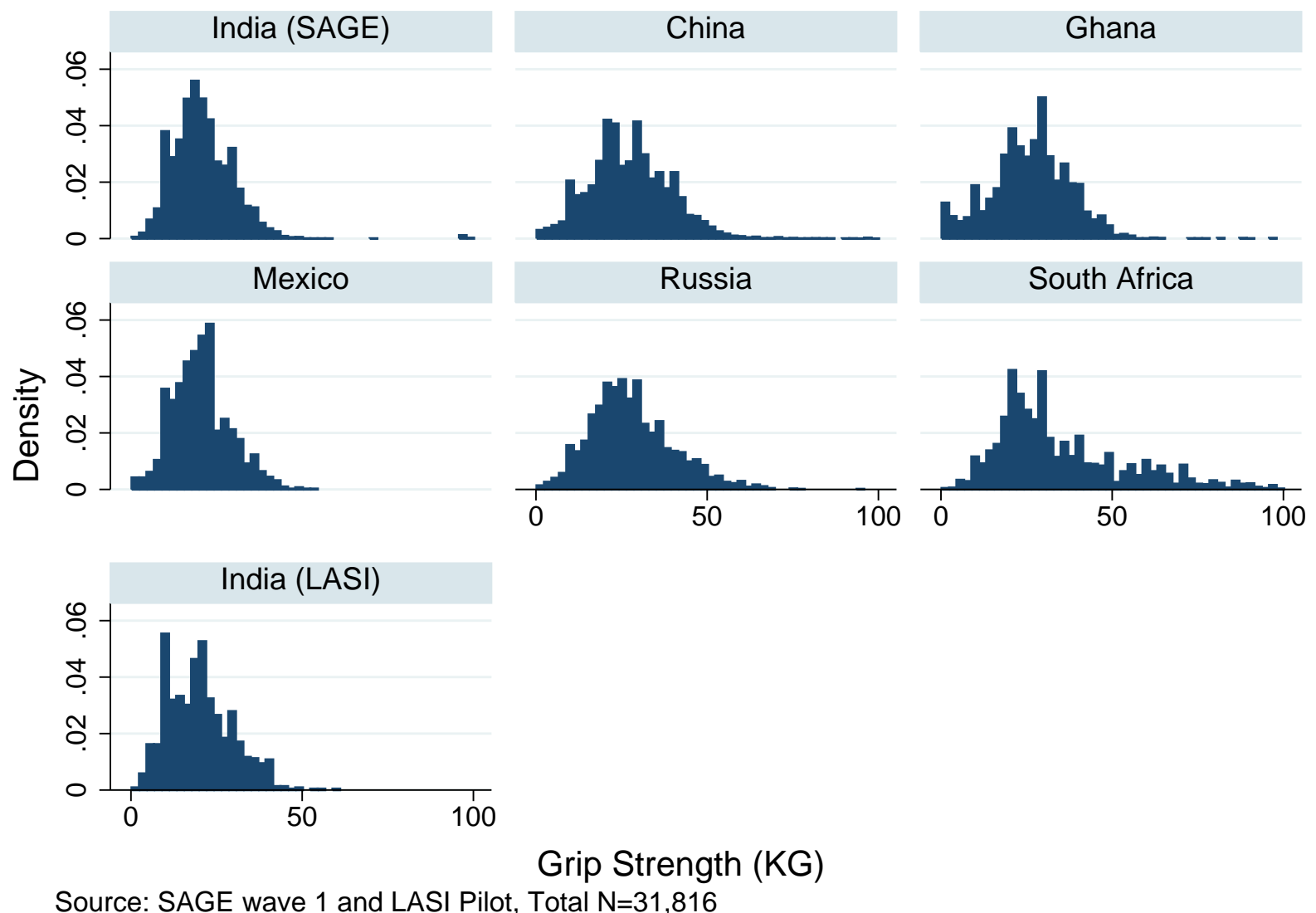

Note: The analysis sample is restricted to those over the age of 45, and those between the 1st and 99th percentiles of the height distribution. Samples are weighted to be nationally representative. 
Figure A3: Distribution of Lung Function by Country

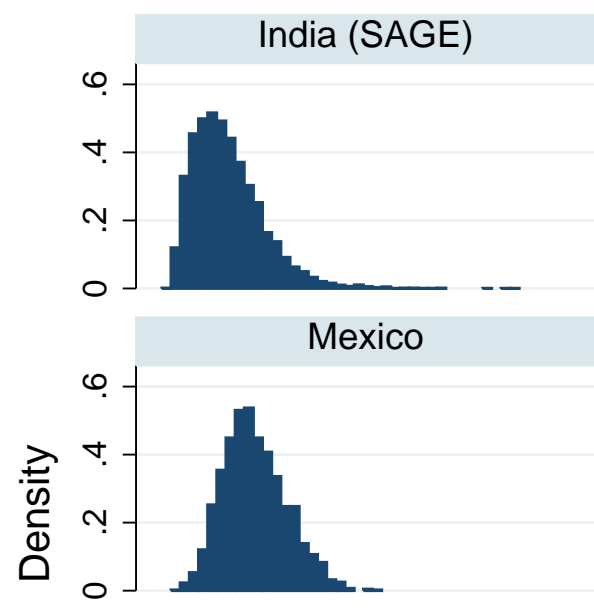

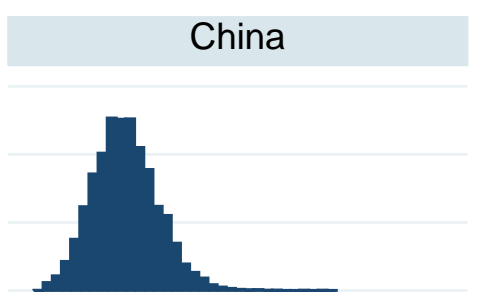

Russia
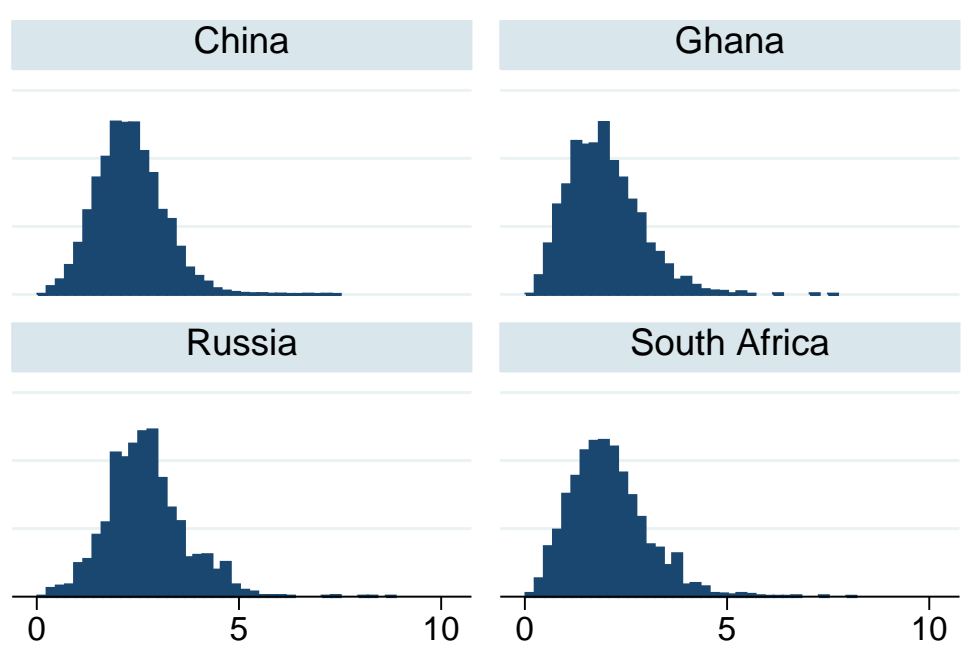

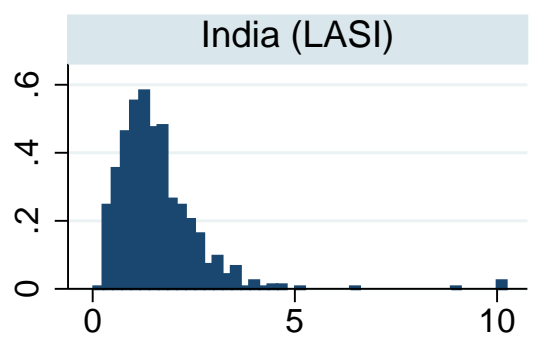

\section{Lung Function (Litres)}

Source: SAGE wave 1 and LASI Pilot, Total $\mathrm{N}=30,847$

Note: The analysis sample is restricted to those over the age of 45, and those between the 1st and 99th percentiles of the height distribution. Samples are weighted to be nationally representative. 
Figure A4: Concentration Curves for Lung Function (Men)
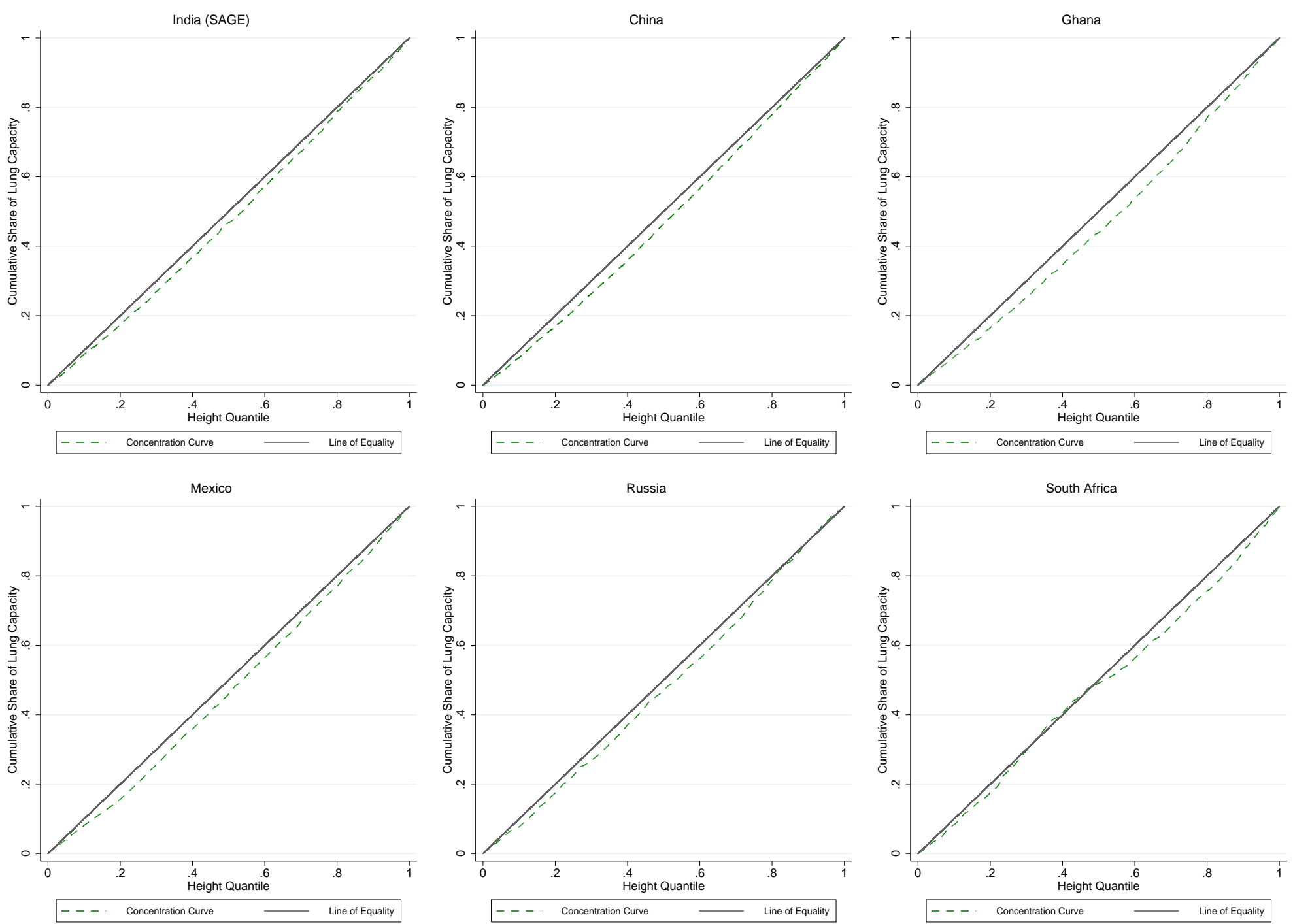

Note: Concentration curves for lung function and height among men are shown for each country. Samples are weighted. Source: WHO SAGE wave1. 
Figure A5: Concentration Curves for Grip Strength (Women)
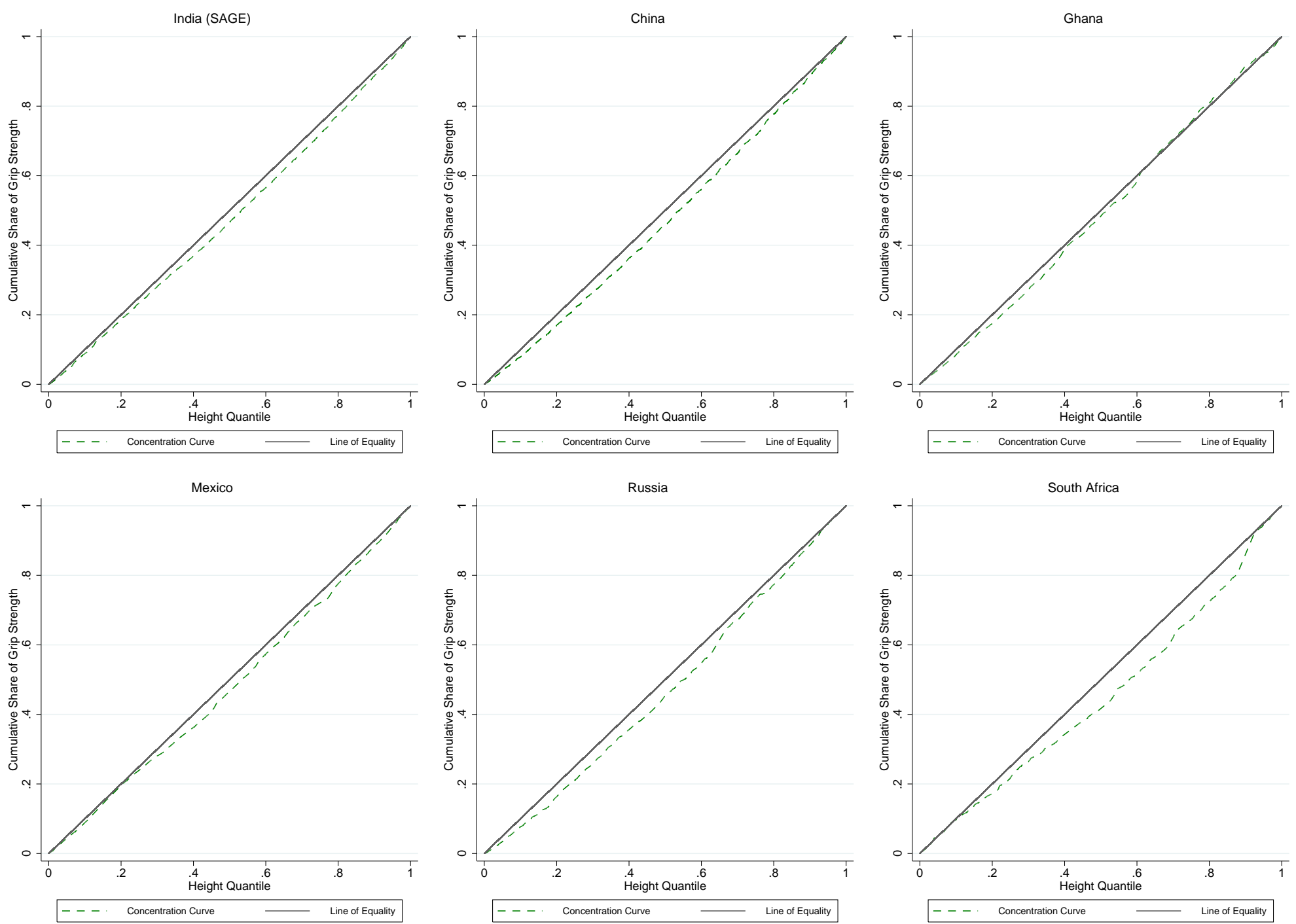

Note: Concentration curves for grip strength and height among women are shown for each country. Samples are weighted. Source: WHO SAGE wave1. 
Figure A6: Concentration Curves for Lung Function (Women)
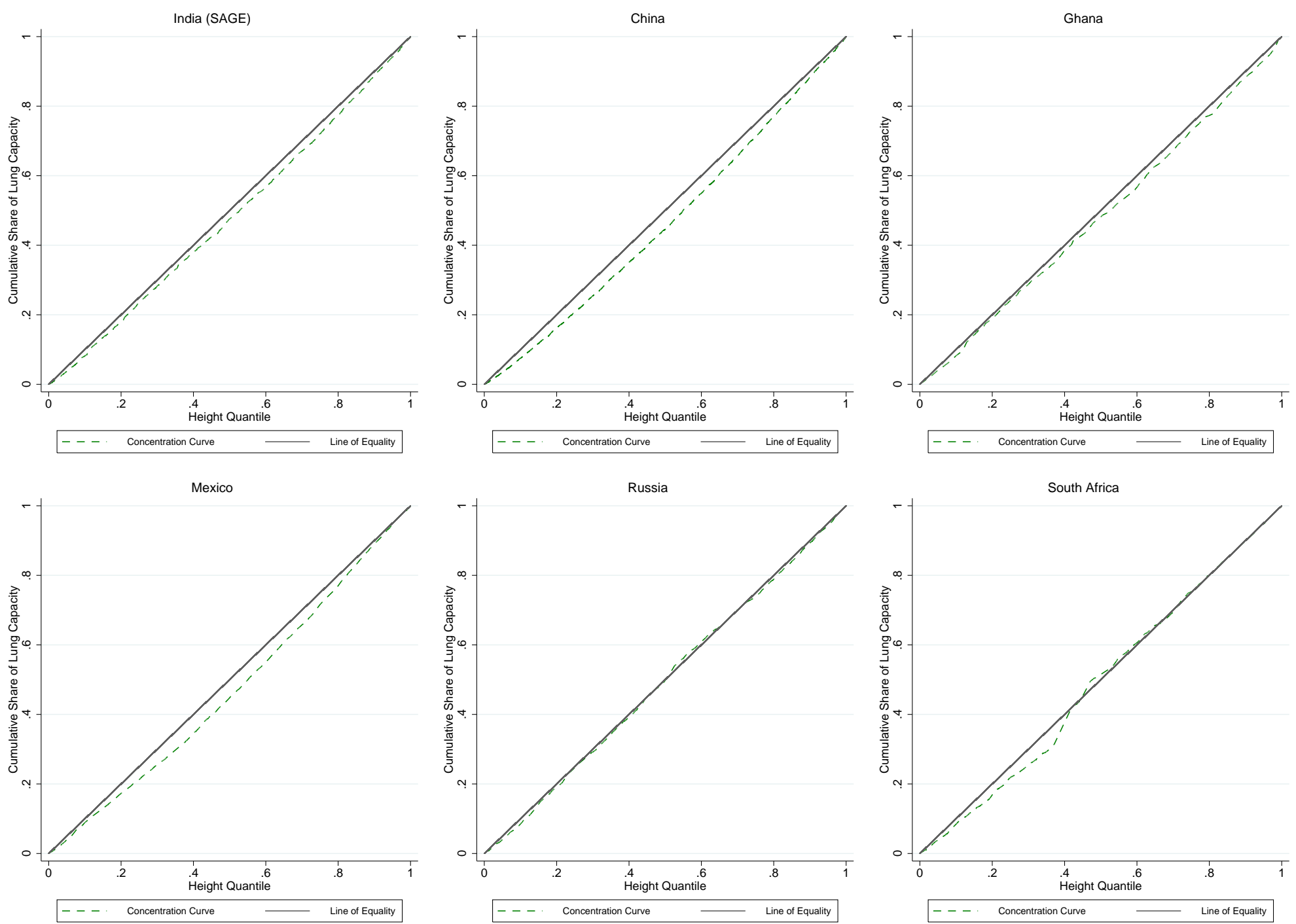

Note: Concentration curves for lung function and height among women are shown for each country. Samples are weighted. Source: WHO SAGE wave1. 
Table A1: The Association Between Height and Grip Strength (Men) by Country

\begin{tabular}{|c|c|c|c|c|c|c|c|c|}
\hline Variables & $\begin{array}{c}\text { Full Sample } \\
\text { OLS }\end{array}$ & $\begin{array}{c}\text { India (S) } \\
\text { OLS }\end{array}$ & $\begin{array}{l}\text { India (L) } \\
\text { OLS }\end{array}$ & $\begin{array}{l}\text { China } \\
\text { OLS }\end{array}$ & $\begin{array}{l}\text { Ghana } \\
\text { OLS }\end{array}$ & $\begin{array}{l}\text { Mexico } \\
\text { OLS }\end{array}$ & $\begin{array}{c}\text { Russia } \\
\text { OLS }\end{array}$ & $\begin{array}{c}\text { South Africa } \\
\text { OLS }\end{array}$ \\
\hline Height (CM) & $\begin{array}{c}0.026^{* * *} \\
(0.002)\end{array}$ & $\begin{array}{c}0.022^{* * * *} \\
(0.002)\end{array}$ & $\begin{array}{c}0.018^{* * * *} \\
(0.005)\end{array}$ & $\begin{array}{c}0.030^{* * * *} \\
(0.003)\end{array}$ & $\begin{array}{c}0.026^{* * *} \\
(0.003)\end{array}$ & $\begin{array}{c}0.014^{* * *} \\
(0.003)\end{array}$ & $\begin{array}{c}0.022^{* * * *} \\
(0.005)\end{array}$ & $\begin{array}{c}0.027^{* * * *} \\
(0.005)\end{array}$ \\
\hline Age & $\begin{array}{c}-0.026^{* * *} \\
(0.001)\end{array}$ & $\begin{array}{c}-0.024^{* * * *} \\
(0.001)\end{array}$ & $\begin{array}{c}-0.020^{* * *} \\
(0.003)\end{array}$ & $\begin{array}{c}-0.029^{* * *} \\
(0.002)\end{array}$ & $\begin{array}{c}-0.019^{* * * *} \\
(0.002)\end{array}$ & $\begin{array}{c}-0.026^{* * *} \\
(0.002)\end{array}$ & $\begin{array}{c}-0.039^{* * *} \\
(0.004)\end{array}$ & $\begin{array}{c}-0.024^{* * *} \\
(0.004)\end{array}$ \\
\hline Mother Had no Education & $\begin{array}{c}0.008 \\
(0.032)\end{array}$ & $\begin{array}{c}0.044 \\
(0.038)\end{array}$ & $\begin{array}{l}-0.120 \\
(0.147)\end{array}$ & $\begin{array}{l}0.092^{*} \\
(0.055)\end{array}$ & $\begin{array}{l}-0.090 \\
(0.103)\end{array}$ & $\begin{array}{l}-0.046 \\
(0.057)\end{array}$ & $\begin{array}{c}0.080 \\
(0.077)\end{array}$ & $\begin{array}{l}-0.044 \\
(0.156)\end{array}$ \\
\hline Mother's Education Missing & $\begin{array}{l}-0.009 \\
(0.052)\end{array}$ & $\begin{array}{l}-0.008 \\
(0.087)\end{array}$ & & $\begin{array}{l}0.015 \\
(0.081)\end{array}$ & $\begin{array}{c}0.177 \\
(0.213)\end{array}$ & $\begin{array}{l}-0.003 \\
(0.083)\end{array}$ & $\begin{array}{c}-0.283^{* *} \\
(0.124)\end{array}$ & $\begin{array}{c}0.127 \\
(0.175)\end{array}$ \\
\hline Father Had no Education & $\begin{array}{c}-0.076^{* *} \\
(0.031)\end{array}$ & $\begin{array}{c}0.017 \\
(0.028)\end{array}$ & $\begin{array}{l}-0.159 \\
(0.141)\end{array}$ & $\begin{array}{c}-0.140^{* *} \\
(0.060)\end{array}$ & $\begin{array}{l}-0.051 \\
(0.079)\end{array}$ & $\begin{array}{l}-0.047 \\
(0.056)\end{array}$ & $\begin{array}{l}-0.043 \\
(0.105)\end{array}$ & $\begin{array}{l}-0.039 \\
(0.135)\end{array}$ \\
\hline Father's Education Missing & $\begin{array}{l}-0.049 \\
(0.046)\end{array}$ & $\begin{array}{c}0.031 \\
(0.063)\end{array}$ & & $\begin{array}{l}-0.045 \\
(0.093)\end{array}$ & $\begin{array}{l}-0.124 \\
(0.177)\end{array}$ & $\begin{array}{l}-0.001 \\
(0.074)\end{array}$ & $\begin{array}{c}0.027 \\
(0.111)\end{array}$ & $\begin{array}{l}-0.136 \\
(0.156)\end{array}$ \\
\hline Constant & $\begin{array}{c}-3.118^{* * *} \\
(0.301)\end{array}$ & $\begin{array}{c}-3.670^{* * *} \\
(0.306)\end{array}$ & $\begin{array}{c}-2.438^{* * *} \\
(0.783)\end{array}$ & $\begin{array}{c}-2.847^{* * *} \\
(0.582)\end{array}$ & $\begin{array}{c}-2.803^{* * *} \\
(0.476)\end{array}$ & $\begin{array}{c}-0.913 \\
(0.645)\end{array}$ & $\begin{array}{c}-0.773 \\
(0.864)\end{array}$ & $\begin{array}{c}-2.200^{*} \\
(1.288)\end{array}$ \\
\hline Observations & 14,755 & 3,261 & 481 & 5,810 & 2,109 & 744 & 1,055 & 1,295 \\
\hline R-squared & 0.262 & 0.176 & 0.201 & 0.183 & 0.131 & 0.212 & 0.209 & 0.070 \\
\hline
\end{tabular}

Clustered standard errors in parentheses

$* * * \mathrm{p}<0.01, * * \mathrm{p}<0.05, * \mathrm{p}<0.1$

Note: Linear regression coefficients are shown, using the model outlined in equation (1), stratified by country and sex with the outcome measured as a Z score. The model indicated by 'Full Sample' is a pooled regression for all countries in the sample, also stratified by sex. Standard errors account for clustering at the PSU level. India (S) refers to SAGE and India (L) refers to LASI. 
Table A2: The Association Between Height and Lung Function (Men) by Country

\begin{tabular}{|c|c|c|c|c|c|c|c|c|}
\hline Variables & $\begin{array}{c}\text { Full Sample } \\
\text { OLS }\end{array}$ & $\begin{array}{c}\text { India (S) } \\
\text { OLS }\end{array}$ & $\begin{array}{l}\text { India (L) } \\
\text { OLS }\end{array}$ & $\begin{array}{c}\text { China } \\
\text { OLS }\end{array}$ & $\begin{array}{c}\text { Ghana } \\
\text { OLS }\end{array}$ & $\begin{array}{l}\text { Mexico } \\
\text { OLS }\end{array}$ & $\begin{array}{c}\text { Russia } \\
\text { OLS }\end{array}$ & $\begin{array}{c}\text { South Africa } \\
\text { OLS }\end{array}$ \\
\hline Height (CM) & $\begin{array}{c}0.028^{* * *} \\
(0.001)\end{array}$ & $\begin{array}{c}0.017^{* * *} \\
(0.003)\end{array}$ & $\begin{array}{c}0.011 \\
(0.010)\end{array}$ & $\begin{array}{c}0.035^{* * *} \\
(0.002)\end{array}$ & $\begin{array}{c}0.033^{* * *} \\
(0.003)\end{array}$ & $\begin{array}{c}0.032^{* * *} \\
(0.004)\end{array}$ & $\begin{array}{c}0.026^{* * *} \\
(0.008)\end{array}$ & $\begin{array}{c}0.024^{* * *} \\
(0.003)\end{array}$ \\
\hline Age & $\begin{array}{c}-0.023^{* * *} \\
(0.001)\end{array}$ & $\begin{array}{c}-0.018^{* * *} \\
(0.002)\end{array}$ & $\begin{array}{c}-0.016^{* * *} \\
(0.004)\end{array}$ & $\begin{array}{c}-0.027^{* * *} \\
(0.002)\end{array}$ & $\begin{array}{c}-0.016^{* * *} \\
(0.002)\end{array}$ & $\begin{array}{c}-0.029^{* * *} \\
(0.003)\end{array}$ & $\begin{array}{c}-0.025^{* * *} \\
(0.005)\end{array}$ & $\begin{array}{c}-0.021^{* * *} \\
(0.003)\end{array}$ \\
\hline Mother Had no Education & $\begin{array}{c}-0.069 * * * \\
(0.024)\end{array}$ & $\begin{array}{c}0.017 \\
(0.051)\end{array}$ & $\begin{array}{l}-0.203 \\
(0.177)\end{array}$ & $\begin{array}{c}-0.090^{* *} \\
(0.039)\end{array}$ & $\begin{array}{l}-0.140 \\
(0.097)\end{array}$ & $\begin{array}{c}-0.042 \\
(0.060)\end{array}$ & $\begin{array}{c}0.062 \\
(0.102)\end{array}$ & $\begin{array}{l}-0.048 \\
(0.076)\end{array}$ \\
\hline Mother's Education Missing & $\begin{array}{l}-0.028 \\
(0.047)\end{array}$ & $\begin{array}{l}-0.137 \\
(0.118)\end{array}$ & & $\begin{array}{c}0.020 \\
(0.066)\end{array}$ & $\begin{array}{l}-0.180 \\
(0.322)\end{array}$ & $\begin{array}{c}0.106 \\
(0.098)\end{array}$ & $\begin{array}{l}-0.185 \\
(0.191)\end{array}$ & $\begin{array}{l}-0.044 \\
(0.097)\end{array}$ \\
\hline Father Had no Education & $\begin{array}{c}-0.012 \\
(0.020)\end{array}$ & $\begin{array}{c}0.030 \\
(0.041)\end{array}$ & $\begin{array}{c}0.077 \\
(0.146)\end{array}$ & $\begin{array}{l}-0.023 \\
(0.031)\end{array}$ & $\begin{array}{l}-0.008 \\
(0.067)\end{array}$ & $\begin{array}{c}0.071 \\
(0.061)\end{array}$ & $\begin{array}{l}-0.043 \\
(0.148)\end{array}$ & $\begin{array}{l}-0.036 \\
(0.084)\end{array}$ \\
\hline Father's Education Missing & $\begin{array}{c}0.021 \\
(0.033)\end{array}$ & $\begin{array}{c}0.009 \\
(0.079)\end{array}$ & & $\begin{array}{c}0.085 \\
(0.052)\end{array}$ & $\begin{array}{c}0.017 \\
(0.184)\end{array}$ & $\begin{array}{c}0.018 \\
(0.086)\end{array}$ & $\begin{array}{c}0.063 \\
(0.104)\end{array}$ & $\begin{array}{l}-0.065 \\
(0.091)\end{array}$ \\
\hline Constant & $\begin{array}{c}-4.279^{* * *} \\
(0.253)\end{array}$ & $\begin{array}{c}-2.678^{* * *} \\
(0.676)\end{array}$ & $\begin{array}{l}-1.205 \\
(1.860)\end{array}$ & $\begin{array}{c}-3.683^{* * *} \\
(0.385)\end{array}$ & $\begin{array}{c}-3.741^{* * *} \\
(0.562)\end{array}$ & $\begin{array}{c}-2.849^{* * *} \\
(0.664)\end{array}$ & $\begin{array}{l}-1.826 \\
(1.517)\end{array}$ & $\begin{array}{c}-2.378^{* * *} \\
(0.573)\end{array}$ \\
\hline Observations & 14,318 & 3,055 & 358 & 5,884 & 2,025 & 746 & 898 & 1,352 \\
\hline R-squared & 0.265 & 0.057 & 0.066 & 0.207 & 0.126 & 0.262 & 0.115 & 0.115 \\
\hline
\end{tabular}

Note: Linear regression coefficients are shown, using the model outlined in equation (1), stratified by country and sex with the outcome measured as a $\mathrm{Z}$ score. The model indicated by 'Full Sample' is a pooled regression for all countries in the sample, also stratified by sex. Standard errors account for clustering at the PSU level. India (S) refers to SAGE and India (L) refers to LASI. 
Table A3: The Association Between Height and Very Good or Good Self-Reported Health (Men) by Country

\begin{tabular}{|c|c|c|c|c|c|c|c|c|}
\hline Variables & $\begin{array}{c}\text { Full Sample } \\
\text { OLS }\end{array}$ & $\begin{array}{l}\text { India (S) } \\
\text { OLS }\end{array}$ & $\begin{array}{c}\text { India }(\mathrm{L}) \\
\text { OLS }\end{array}$ & $\begin{array}{c}\text { China } \\
\text { OLS }\end{array}$ & $\begin{array}{c}\text { Ghana } \\
\text { OLS }\end{array}$ & $\begin{array}{l}\text { Mexico } \\
\text { OLS }\end{array}$ & $\begin{array}{c}\text { Russia } \\
\text { OLS }\end{array}$ & $\begin{array}{c}\text { South Africa } \\
\text { OLS }\end{array}$ \\
\hline Height (CM) & $\begin{array}{c}0.003^{* * *} \\
(0.001)\end{array}$ & $\begin{array}{c}0.003^{* * *} \\
(0.001)\end{array}$ & $\begin{array}{c}0.008^{* * *} \\
(0.003)\end{array}$ & $\begin{array}{c}0.004^{* * *} \\
(0.001)\end{array}$ & $\begin{array}{l}-0.001 \\
(0.002)\end{array}$ & $\begin{array}{c}0.000 \\
(0.002)\end{array}$ & $\begin{array}{c}0.003^{* *} \\
(0.001)\end{array}$ & $\begin{array}{c}0.004^{* *} \\
(0.002)\end{array}$ \\
\hline Age & $\begin{array}{c}-0.010^{* * *} \\
(0.000)\end{array}$ & $\begin{array}{c}-0.010^{* * *} \\
(0.001)\end{array}$ & $\begin{array}{c}-0.012^{* * *} \\
(0.002)\end{array}$ & $\begin{array}{c}-0.009^{* * *} \\
(0.001)\end{array}$ & $\begin{array}{c}-0.013^{* * *} \\
(0.001)\end{array}$ & $\begin{array}{l}-0.002 \\
(0.002)\end{array}$ & $\begin{array}{c}-0.008^{* * *} \\
(0.001)\end{array}$ & $\begin{array}{c}-0.008^{* * *} \\
(0.002)\end{array}$ \\
\hline Mother Had no Education & $\begin{array}{l}-0.011 \\
(0.015)\end{array}$ & $\begin{array}{l}-0.045 \\
(0.029)\end{array}$ & $\begin{array}{c}0.213^{* *} \\
(0.093)\end{array}$ & $\begin{array}{l}-0.030 \\
(0.026)\end{array}$ & $\begin{array}{l}-0.035 \\
(0.049)\end{array}$ & $\begin{array}{l}-0.022 \\
(0.048)\end{array}$ & $\begin{array}{l}-0.042^{*} \\
(0.023)\end{array}$ & $\begin{array}{c}0.014 \\
(0.046)\end{array}$ \\
\hline Mother's Education Missing & $\begin{array}{l}-0.042 \\
(0.026)\end{array}$ & $\begin{array}{l}-0.034 \\
(0.072)\end{array}$ & & $\begin{array}{l}-0.041 \\
(0.048)\end{array}$ & $\begin{array}{l}-0.025 \\
(0.099)\end{array}$ & $\begin{array}{c}-0.138^{* *} \\
(0.064)\end{array}$ & $\begin{array}{c}0.018 \\
(0.054)\end{array}$ & $\begin{array}{l}-0.080 \\
(0.055)\end{array}$ \\
\hline Father Had no Education & $\begin{array}{c}-0.039 * * * \\
(0.011)\end{array}$ & $\begin{array}{c}-0.068^{* * *} \\
(0.020)\end{array}$ & $\begin{array}{c}0.208^{* *} \\
(0.081)\end{array}$ & $\begin{array}{l}-0.023 \\
(0.017)\end{array}$ & $\begin{array}{c}-0.076^{* *} \\
(0.035)\end{array}$ & $\begin{array}{c}-0.132^{* * *} \\
(0.043)\end{array}$ & $\begin{array}{l}-0.033 \\
(0.028)\end{array}$ & $\begin{array}{c}-0.041 \\
(0.046)\end{array}$ \\
\hline Father's Education Missing & $\begin{array}{l}-0.009 \\
(0.021)\end{array}$ & $\begin{array}{c}-0.057 \\
(0.056)\end{array}$ & & $\begin{array}{c}0.015 \\
(0.037)\end{array}$ & $\begin{array}{l}-0.064 \\
(0.092)\end{array}$ & $\begin{array}{c}-0.109^{*} \\
(0.063)\end{array}$ & $\begin{array}{c}0.028 \\
(0.043)\end{array}$ & $\begin{array}{c}0.007 \\
(0.051)\end{array}$ \\
\hline Constant & $\begin{array}{c}0.929 * * * \\
(0.124)\end{array}$ & $\begin{array}{c}0.326 \\
(0.233)\end{array}$ & $\begin{array}{l}-0.376 \\
(0.507)\end{array}$ & $\begin{array}{c}0.260 \\
(0.256)\end{array}$ & $\begin{array}{c}1.958^{* * *} \\
(0.251)\end{array}$ & $\begin{array}{c}0.662 \\
(0.435)\end{array}$ & $\begin{array}{c}0.315 \\
(0.256)\end{array}$ & $\begin{array}{l}0.604^{*} \\
(0.309)\end{array}$ \\
\hline Observations & 15,632 & 3,399 & 531 & 5,930 & 2,271 & 801 & 1,224 & 1,476 \\
\hline R-squared & 0.081 & 0.056 & 0.204 & 0.045 & 0.093 & 0.041 & 0.061 & 0.048 \\
\hline
\end{tabular}

Clustered standard errors in parentheses

$$
* * * \mathrm{p}<0.01, * * \mathrm{p}<0.05, * \mathrm{p}<0.1
$$

Note: Linear regression coefficients are shown, using the model outlined in equation (1), stratified by country and sex with the outcome measured as a binary indicator for being in very good or good self-reported health. The model indicated by 'Full Sample' is a pooled regression for all countries in the sample, also stratified by sex. Standard errors account for clustering at the PSU level. India (S) refers to SAGE and India (L) refers to LASI. 
Table A4: The Association Between Height and No Difficulties with ADL or IADL (Men) by Country

\begin{tabular}{|c|c|c|c|c|c|c|c|}
\hline Variables & $\begin{array}{c}\text { Full Sample } \\
\text { OLS }\end{array}$ & $\begin{array}{c}\text { India }(\mathrm{S}) \\
\text { OLS }\end{array}$ & $\begin{array}{c}\text { China } \\
\text { OLS }\end{array}$ & $\begin{array}{c}\text { Ghana } \\
\text { OLS }\end{array}$ & $\begin{array}{c}\text { Mexico } \\
\text { OLS }\end{array}$ & $\begin{array}{c}\text { Russia } \\
\text { OLS }\end{array}$ & $\begin{array}{c}\text { South Africa } \\
\text { OLS }\end{array}$ \\
\hline Height (CM) & $\begin{array}{c}0.003^{* * *} \\
(0.001)\end{array}$ & $\begin{array}{c}0.003^{* *} \\
(0.001)\end{array}$ & $\begin{array}{c}0.004^{* * *} \\
(0.001)\end{array}$ & $\begin{array}{c}0.001 \\
(0.002)\end{array}$ & $\begin{array}{c}0.001 \\
(0.002)\end{array}$ & $\begin{array}{l}0.004^{*} \\
(0.002)\end{array}$ & $\begin{array}{l}0.003^{*} \\
(0.002)\end{array}$ \\
\hline Age & $\begin{array}{c}-0.014^{* * *} \\
(0.000)\end{array}$ & $\begin{array}{c}-0.012^{* * *} \\
(0.001)\end{array}$ & $\begin{array}{c}-0.014^{* * *} \\
(0.001)\end{array}$ & $\begin{array}{c}-0.014^{* * *} \\
(0.001)\end{array}$ & $\begin{array}{c}-0.014^{* * *} \\
(0.002)\end{array}$ & $\begin{array}{c}-0.017^{* * *} \\
(0.001)\end{array}$ & $\begin{array}{c}-0.011^{* * *} \\
(0.002)\end{array}$ \\
\hline Mother Had no Education & $\begin{array}{c}-0.028^{* *} \\
(0.014)\end{array}$ & $\begin{array}{l}-0.049 \\
(0.034)\end{array}$ & $\begin{array}{c}0.010 \\
(0.020)\end{array}$ & $\begin{array}{c}0.056 \\
(0.048)\end{array}$ & $\begin{array}{c}0.007 \\
(0.042)\end{array}$ & $\begin{array}{c}-0.147^{* * *} \\
(0.042)\end{array}$ & $\begin{array}{l}-0.049 \\
(0.040)\end{array}$ \\
\hline Mother's Education Missing & $\begin{array}{l}-0.025 \\
(0.022)\end{array}$ & $\begin{array}{c}-0.175^{* * *} \\
(0.053)\end{array}$ & $\begin{array}{c}0.031 \\
(0.032)\end{array}$ & $\begin{array}{c}0.050 \\
(0.099)\end{array}$ & $\begin{array}{c}0.063 \\
(0.068)\end{array}$ & $\begin{array}{l}-0.104^{*} \\
(0.063)\end{array}$ & $\begin{array}{l}-0.023 \\
(0.050)\end{array}$ \\
\hline Father Had no Education & $\begin{array}{c}-0.055^{* * *} \\
(0.012)\end{array}$ & $\begin{array}{c}-0.046^{* *} \\
(0.021)\end{array}$ & $\begin{array}{c}-0.060^{* * *} \\
(0.019)\end{array}$ & $\begin{array}{c}-0.074^{* *} \\
(0.033)\end{array}$ & $\begin{array}{c}-0.126^{* * *} \\
(0.044)\end{array}$ & $\begin{array}{c}0.029 \\
(0.059)\end{array}$ & $\begin{array}{l}-0.046 \\
(0.040)\end{array}$ \\
\hline Father's Education Missing & $\begin{array}{l}-0.028 \\
(0.020)\end{array}$ & $\begin{array}{l}-0.058 \\
(0.048)\end{array}$ & $\begin{array}{l}-0.024 \\
(0.034)\end{array}$ & $\begin{array}{c}0.038 \\
(0.077)\end{array}$ & $\begin{array}{l}-0.097 \\
(0.068)\end{array}$ & $\begin{array}{c}0.013 \\
(0.048)\end{array}$ & $\begin{array}{l}-0.042 \\
(0.049)\end{array}$ \\
\hline Constant & $\begin{array}{c}0.221 \\
(0.273)\end{array}$ & $\begin{array}{c}0.770^{* * *} \\
(0.253)\end{array}$ & $\begin{array}{c}0.825^{* * *} \\
(0.225)\end{array}$ & $\begin{array}{l}0.510^{*} \\
(0.303)\end{array}$ & $\begin{array}{c}1.276^{* * *} \\
(0.424)\end{array}$ & $\begin{array}{l}1.036^{* *} \\
(0.414)\end{array}$ & $\begin{array}{c}0.892^{* * *} \\
(0.300)\end{array}$ \\
\hline Observations & 15,132 & 3,399 & 5,940 & 2,271 & 817 & 1,226 & 1,479 \\
\hline $\mathrm{R}$-squared & 0.222 & 0.091 & 0.108 & 0.118 & 0.129 & 0.174 & 0.064 \\
\hline
\end{tabular}

Clustered standard errors in parentheses

$* * * \mathrm{p}<0.01,{ }^{*} * \mathrm{p}<0.05, * \mathrm{p}<0.1$

Note: Linear regression coefficients are shown, using the model outlined in equation (1), stratified by country and sex with the outcome measured as a binary indicator for having no difficulties with activities of daily living or instrumental activities of daily living. The model indicated by 'Full Sample' is a pooled regression for all countries in the sample, also stratified by sex. Standard errors account for clustering at the PSU level. India (S) refers to SAGE. 
Table A5: The Association Between Height and Grip Strength (Women) by Country

\begin{tabular}{|c|c|c|c|c|c|c|c|c|}
\hline Variables & $\begin{array}{c}\text { Full Sample } \\
\text { OLS }\end{array}$ & $\begin{array}{c}\text { India }(\mathrm{S}) \\
\text { OLS }\end{array}$ & $\begin{array}{c}\text { India }(\mathrm{L}) \\
\text { OLS }\end{array}$ & $\begin{array}{l}\text { China } \\
\text { OLS }\end{array}$ & $\begin{array}{c}\text { Ghana } \\
\text { OLS }\end{array}$ & $\begin{array}{c}\text { Mexico } \\
\text { OLS }\end{array}$ & $\begin{array}{c}\text { Russia } \\
\text { OLS }\end{array}$ & $\begin{array}{c}\text { South Africa } \\
\text { OLS }\end{array}$ \\
\hline Height $(\mathrm{CM})$ & $\begin{array}{c}0.018^{* * *} \\
(0.002)\end{array}$ & $\begin{array}{c}0.017^{* * *} \\
(0.002)\end{array}$ & $\begin{array}{c}0.016^{* * *} \\
(0.004)\end{array}$ & $\begin{array}{c}0.020^{* * *} \\
(0.005)\end{array}$ & $\begin{array}{l}0.006^{*} \\
(0.003)\end{array}$ & $\begin{array}{c}0.013^{* * *} \\
(0.003)\end{array}$ & $\begin{array}{c}0.022^{* * *} \\
(0.004)\end{array}$ & $\begin{array}{c}0.024^{* * *} \\
(0.005)\end{array}$ \\
\hline Age & $\begin{array}{c}-0.020^{* * *} \\
(0.001)\end{array}$ & $\begin{array}{c}-0.014^{* * *} \\
(0.002)\end{array}$ & $\begin{array}{c}-0.014^{* * *} \\
(0.002)\end{array}$ & $\begin{array}{c}-0.021^{* * *} \\
(0.003)\end{array}$ & $\begin{array}{c}-0.018^{* * *} \\
(0.002)\end{array}$ & $\begin{array}{c}-0.015^{* * *} \\
(0.002)\end{array}$ & $\begin{array}{c}-0.029^{* * *} \\
(0.003)\end{array}$ & $\begin{array}{c}-0.023^{* * *} \\
(0.004)\end{array}$ \\
\hline Mother Had no Education & $\begin{array}{c}0.014 \\
(0.029)\end{array}$ & $\begin{array}{c}0.060 \\
(0.049)\end{array}$ & $\begin{array}{c}0.061 \\
(0.086)\end{array}$ & $\begin{array}{c}0.068 \\
(0.059)\end{array}$ & $\begin{array}{l}-0.017 \\
(0.119)\end{array}$ & $\begin{array}{l}-0.026 \\
(0.043)\end{array}$ & $\begin{array}{c}0.016 \\
(0.054)\end{array}$ & $\begin{array}{l}-0.071 \\
(0.125)\end{array}$ \\
\hline Mother's Education Missing & $\begin{array}{l}-0.006 \\
(0.056)\end{array}$ & $\begin{array}{l}-0.065 \\
(0.122)\end{array}$ & & $\begin{array}{c}0.140 \\
(0.116)\end{array}$ & $\begin{array}{c}0.340 \\
(0.271)\end{array}$ & $\begin{array}{l}-0.076 \\
(0.069)\end{array}$ & $\begin{array}{l}-0.050 \\
(0.070)\end{array}$ & $\begin{array}{l}-0.096 \\
(0.168)\end{array}$ \\
\hline Father Had no Education & $\begin{array}{l}-0.027 \\
(0.030)\end{array}$ & $\begin{array}{l}-0.016 \\
(0.033)\end{array}$ & $\begin{array}{c}-0.170^{* *} \\
(0.084)\end{array}$ & $\begin{array}{l}-0.066 \\
(0.058)\end{array}$ & $\begin{array}{c}0.002 \\
(0.081)\end{array}$ & $\begin{array}{c}0.011 \\
(0.042)\end{array}$ & $\begin{array}{c}0.065 \\
(0.053)\end{array}$ & $\begin{array}{c}0.118 \\
(0.111)\end{array}$ \\
\hline Father's Education Missing & $\begin{array}{l}-0.050 \\
(0.038)\end{array}$ & $\begin{array}{c}0.028 \\
(0.050)\end{array}$ & & $\begin{array}{l}-0.046 \\
(0.064)\end{array}$ & $\begin{array}{l}-0.057 \\
(0.138)\end{array}$ & $\begin{array}{l}-0.005 \\
(0.051)\end{array}$ & $\begin{array}{l}-0.066 \\
(0.082)\end{array}$ & $\begin{array}{l}-0.042 \\
(0.140)\end{array}$ \\
\hline Constant & $\begin{array}{c}-2.102^{* * *} \\
(0.466)\end{array}$ & $\begin{array}{c}-2.274^{* * *} \\
(0.426)\end{array}$ & $\begin{array}{c}-2.233^{* * *} \\
(0.668)\end{array}$ & $\begin{array}{c}-1.862^{* *} \\
(0.845)\end{array}$ & $\begin{array}{c}0.856 \\
(0.641)\end{array}$ & $\begin{array}{c}-1.329^{* *} \\
(0.521)\end{array}$ & $\begin{array}{c}-1.797^{* *} \\
(0.689)\end{array}$ & $\begin{array}{c}-2.707^{* * *} \\
(0.869)\end{array}$ \\
\hline Observations & 17,032 & 3,336 & 514 & 6,637 & 1,841 & 1,116 & 1,880 & 1,708 \\
\hline R-squared & 0.220 & 0.068 & 0.137 & 0.102 & 0.082 & 0.140 & 0.210 & 0.065 \\
\hline
\end{tabular}

Clustered standard errors in parentheses

$* * * \mathrm{p}<0.01,{ }^{*} * \mathrm{p}<0.05,{ }^{*} \mathrm{p}<0.1$

Note: Linear regression coefficients are shown, using the model outlined in equation (1), stratified by country and sex with the outcome measured as a $\mathrm{Z}$ score. The model indicated by 'Full Sample' is a pooled regression for all countries in the sample, also stratified by sex. Standard errors account for clustering at the PSU level. India (S) refers to SAGE and India (L) refers to LASI. 
Table A6: The Association Between Height and Lung Function (Women) by Country

\begin{tabular}{|c|c|c|c|c|c|c|c|c|}
\hline Variables & $\begin{array}{c}\text { Full Sample } \\
\text { OLS }\end{array}$ & $\begin{array}{c}\text { India (S) } \\
\text { OLS }\end{array}$ & $\begin{array}{c}\text { India (L) } \\
\text { OLS }\end{array}$ & $\begin{array}{c}\text { China } \\
\text { OLS }\end{array}$ & $\begin{array}{l}\text { Ghana } \\
\text { OLS }\end{array}$ & $\begin{array}{l}\text { Mexico } \\
\text { OLS }\end{array}$ & $\begin{array}{c}\text { Russia } \\
\text { OLS }\end{array}$ & $\begin{array}{c}\text { South Africa } \\
\text { OLS }\end{array}$ \\
\hline Height (CM) & $\begin{array}{c}0.028^{* * *} \\
(0.001)\end{array}$ & $\begin{array}{c}0.020^{* * *} \\
(0.003)\end{array}$ & $\begin{array}{c}0.014 \\
(0.014)\end{array}$ & $\begin{array}{c}0.035^{* * *} \\
(0.002)\end{array}$ & $\begin{array}{c}0.021^{* * *} \\
(0.003)\end{array}$ & $\begin{array}{c}0.029^{* * *} \\
(0.003)\end{array}$ & $\begin{array}{c}0.015^{* *} \\
(0.008)\end{array}$ & $\begin{array}{c}0.025^{* * *} \\
(0.004)\end{array}$ \\
\hline Age & $\begin{array}{c}-0.019^{* * * *} \\
(0.001)\end{array}$ & $\begin{array}{c}-0.009^{* * *} \\
(0.002)\end{array}$ & $\begin{array}{c}0.002 \\
(0.007)\end{array}$ & $\begin{array}{c}-0.023^{* * *} \\
(0.002)\end{array}$ & $\begin{array}{c}-0.011^{* * *} \\
(0.002)\end{array}$ & $\begin{array}{c}-0.024^{* * *} \\
(0.002)\end{array}$ & $\begin{array}{c}-0.022^{* * *} \\
(0.004)\end{array}$ & $\begin{array}{c}-0.020^{* * *} \\
(0.003)\end{array}$ \\
\hline Mother Had no Education & $\begin{array}{c}-0.076^{* * *} \\
(0.027)\end{array}$ & $\begin{array}{c}0.069 \\
(0.058)\end{array}$ & $\begin{array}{l}0.284^{*} \\
(0.153)\end{array}$ & $\begin{array}{c}-0.103^{* *} \\
(0.040)\end{array}$ & $\begin{array}{l}-0.159^{*} \\
(0.095)\end{array}$ & $\begin{array}{l}-0.032 \\
(0.053)\end{array}$ & $\begin{array}{l}-0.153 \\
(0.098)\end{array}$ & $\begin{array}{l}-0.078 \\
(0.082)\end{array}$ \\
\hline Mother's Education Missing & $\begin{array}{c}-0.108^{* *} \\
(0.045)\end{array}$ & $\begin{array}{c}-0.207^{* *} \\
(0.098)\end{array}$ & & $\begin{array}{l}-0.058 \\
(0.075)\end{array}$ & $\begin{array}{c}-0.543^{* * *} \\
(0.195)\end{array}$ & $\begin{array}{l}-0.050 \\
(0.069)\end{array}$ & $\begin{array}{l}-0.088 \\
(0.155)\end{array}$ & $\begin{array}{l}-0.087 \\
(0.100)\end{array}$ \\
\hline Father Had no Education & $\begin{array}{l}-0.018 \\
(0.019)\end{array}$ & $\begin{array}{l}-0.025 \\
(0.048)\end{array}$ & $\begin{array}{c}0.153 \\
(0.150)\end{array}$ & $\begin{array}{l}-0.033 \\
(0.026)\end{array}$ & $\begin{array}{c}0.061 \\
(0.064)\end{array}$ & $\begin{array}{l}-0.028 \\
(0.048)\end{array}$ & $\begin{array}{c}0.018 \\
(0.093)\end{array}$ & $\begin{array}{c}0.006 \\
(0.079)\end{array}$ \\
\hline Father's Education Missing & $\begin{array}{c}0.006 \\
(0.029)\end{array}$ & $\begin{array}{c}0.068 \\
(0.085)\end{array}$ & & $\begin{array}{l}-0.083^{*} \\
(0.045)\end{array}$ & $\begin{array}{c}0.059 \\
(0.099)\end{array}$ & $\begin{array}{l}-0.080 \\
(0.054)\end{array}$ & $\begin{array}{c}0.029 \\
(0.081)\end{array}$ & $\begin{array}{c}0.088 \\
(0.082)\end{array}$ \\
\hline Constant & $\begin{array}{c}-4.198^{* * *} \\
(0.910)\end{array}$ & $\begin{array}{c}-3.078^{* * *} \\
(0.517)\end{array}$ & $\begin{array}{l}-3.304 \\
(2.199)\end{array}$ & $\begin{array}{c}-3.741 * * * \\
(0.418)\end{array}$ & $\begin{array}{c}-2.552^{* * *} \\
(0.636)\end{array}$ & $\begin{array}{c}-2.651^{* * *} \\
(0.479)\end{array}$ & $\begin{array}{l}-0.803 \\
(1.260)\end{array}$ & $\begin{array}{c}-3.028^{* * * *} \\
(0.592)\end{array}$ \\
\hline Observations & 16,506 & 3,053 & 356 & 6,767 & 1,709 & 1,159 & 1,639 & 1,823 \\
\hline R-squared & 0.232 & 0.033 & 0.045 & 0.214 & 0.063 & 0.256 & 0.083 & 0.098 \\
\hline
\end{tabular}

Clustered standard errors in parentheses

$$
* * * \mathrm{p}<0.01, * * \mathrm{p}<0.05, * \mathrm{p}<0.1
$$

Note: Linear regression coefficients are shown, using the model outlined in equation (1), stratified by country and sex with the outcome measured as a Z score. The model indicated by 'Full Sample' is a pooled regression for all countries in the sample, also stratified by sex. Standard errors account for clustering at the PSU level. India (S) refers to SAGE and India (L) refers to LASI. 
Table A7: The Association Between Height and Very Good or Good Self-Reported Health (Women) by Country

\begin{tabular}{|c|c|c|c|c|c|c|c|c|}
\hline Variables & $\begin{array}{c}\text { Full Sample } \\
\text { OLS }\end{array}$ & $\begin{array}{c}\text { India (S) } \\
\text { OLS }\end{array}$ & $\begin{array}{c}\text { India (L) } \\
\text { OLS }\end{array}$ & $\begin{array}{l}\text { China } \\
\text { OLS }\end{array}$ & $\begin{array}{c}\text { Ghana } \\
\text { OLS }\end{array}$ & $\begin{array}{l}\text { Mexico } \\
\text { OLS }\end{array}$ & $\begin{array}{c}\text { Russia } \\
\text { OLS }\end{array}$ & $\begin{array}{c}\text { South Africa } \\
\text { OLS }\end{array}$ \\
\hline Height $(\mathrm{CM})$ & $\begin{array}{c}0.002^{* * *} \\
(0.001)\end{array}$ & $\begin{array}{c}0.001 \\
(0.001)\end{array}$ & $\begin{array}{l}0.006^{*} \\
(0.003)\end{array}$ & $\begin{array}{c}0.002^{* *} \\
(0.001)\end{array}$ & $\begin{array}{c}0.001 \\
(0.002)\end{array}$ & $\begin{array}{l}-0.003 \\
(0.002)\end{array}$ & $\begin{array}{c}0.005^{* * * *} \\
(0.001)\end{array}$ & $\begin{array}{c}0.004^{* *} \\
(0.001)\end{array}$ \\
\hline Age & $\begin{array}{c}-0.007^{* * *} \\
(0.000)\end{array}$ & $\begin{array}{c}-0.006^{* * *} \\
(0.001)\end{array}$ & $\begin{array}{c}-0.013^{* * *} \\
(0.002)\end{array}$ & $\begin{array}{c}-0.005^{* * *} \\
(0.001)\end{array}$ & $\begin{array}{c}-0.011^{* * *} \\
(0.001)\end{array}$ & $\begin{array}{l}-0.001 \\
(0.002)\end{array}$ & $\begin{array}{c}-0.005^{* * *} \\
(0.001)\end{array}$ & $\begin{array}{c}-0.008^{* * *} \\
(0.001)\end{array}$ \\
\hline Mother Had no Education & $\begin{array}{l}-0.022^{*} \\
(0.012)\end{array}$ & $\begin{array}{l}-0.027 \\
(0.032)\end{array}$ & $\begin{array}{c}0.264^{* * *} \\
(0.059)\end{array}$ & $\begin{array}{c}-0.065^{* * *} \\
(0.021)\end{array}$ & $\begin{array}{l}-0.053 \\
(0.056)\end{array}$ & $\begin{array}{l}-0.046 \\
(0.035)\end{array}$ & $\begin{array}{c}-0.029^{* *} \\
(0.013)\end{array}$ & $\begin{array}{l}-0.002 \\
(0.035)\end{array}$ \\
\hline Mother's Education Missing & $\begin{array}{c}-0.044^{* *} \\
(0.019)\end{array}$ & $\begin{array}{l}-0.069 \\
(0.055)\end{array}$ & & $\begin{array}{l}-0.019 \\
(0.041)\end{array}$ & $\begin{array}{l}-0.132 \\
(0.105)\end{array}$ & $\begin{array}{l}-0.059 \\
(0.057)\end{array}$ & $\begin{array}{c}-0.039^{* *} \\
(0.020)\end{array}$ & $\begin{array}{c}-0.084^{* *} \\
(0.039)\end{array}$ \\
\hline Father Had no Education & $\begin{array}{c}-0.026^{* *} \\
(0.010)\end{array}$ & $\begin{array}{l}-0.020 \\
(0.020)\end{array}$ & $\begin{array}{l}0.151^{* *} \\
(0.058)\end{array}$ & $\begin{array}{l}-0.033^{*} \\
(0.017)\end{array}$ & $\begin{array}{l}-0.048 \\
(0.032)\end{array}$ & $\begin{array}{l}-0.054^{*} \\
(0.032)\end{array}$ & $\begin{array}{l}-0.010 \\
(0.021)\end{array}$ & $\begin{array}{l}-0.043 \\
(0.035)\end{array}$ \\
\hline Father's Education Missing & $\begin{array}{c}-0.033^{* *} \\
(0.014)\end{array}$ & $\begin{array}{l}-0.002 \\
(0.036)\end{array}$ & & $\begin{array}{l}-0.054 \\
(0.033)\end{array}$ & $\begin{array}{l}-0.027 \\
(0.065)\end{array}$ & $\begin{array}{c}-0.109^{* * *} \\
(0.042)\end{array}$ & $\begin{array}{l}-0.020 \\
(0.017)\end{array}$ & $\begin{array}{l}-0.038 \\
(0.035)\end{array}$ \\
\hline Constant & $\begin{array}{c}0.255 \\
(0.297)\end{array}$ & $\begin{array}{l}0.399^{*} \\
(0.230)\end{array}$ & $\begin{array}{c}-0.096 \\
(0.530)\end{array}$ & $\begin{array}{c}0.281 \\
(0.185)\end{array}$ & $\begin{array}{c}0.656^{* *} \\
(0.279)\end{array}$ & $\begin{array}{c}0.913^{* *} \\
(0.377)\end{array}$ & $\begin{array}{c}-0.208 \\
(0.259)\end{array}$ & $\begin{array}{c}0.632 \\
(0.478)\end{array}$ \\
\hline Observations & 18,527 & 3,531 & 585 & 6,837 & 2,037 & 1,258 & 2,297 & 1,982 \\
\hline R-squared & 0.074 & 0.025 & 0.192 & 0.023 & 0.089 & 0.014 & 0.065 & 0.081 \\
\hline
\end{tabular}

$$
* * * \mathrm{p}<0.01, * * \mathrm{p}<0.05,{ }^{*} \mathrm{p}<0.1
$$

Note: Linear regression coefficients are shown, using the model outlined in equation (1), stratified by country and sex with the outcome measured as a binary indicator for being in very good or good self-reported health. The model indicated by All is a pooled regression for all countries in the sample, also stratified by sex. Standard errors account for clustering at the PSU level. India (S) refers to SAGE and India (L) refers to LASI. 
Table A8: The Association Between Height and No Difficulties with ADL or IADL (Women) by Country

\begin{tabular}{|c|c|c|c|c|c|c|c|}
\hline Variables & $\begin{array}{c}\text { Full Sample } \\
\text { OLS }\end{array}$ & $\begin{array}{c}\text { India (S) } \\
\text { OLS }\end{array}$ & $\begin{array}{c}\text { China } \\
\text { OLS }\end{array}$ & $\begin{array}{c}\text { Ghana } \\
\text { OLS }\end{array}$ & $\begin{array}{c}\text { Mexico } \\
\text { OLS }\end{array}$ & $\begin{array}{c}\text { Russia } \\
\text { OLS }\end{array}$ & $\begin{array}{c}\text { South Africa } \\
\text { OLS }\end{array}$ \\
\hline Height $(\mathrm{CM})$ & $\begin{array}{c}0.003^{* * *} \\
(0.001)\end{array}$ & $\begin{array}{c}0.002^{* *} \\
(0.001)\end{array}$ & $\begin{array}{c}0.005^{* * *} \\
(0.001)\end{array}$ & $\begin{array}{l}-0.001 \\
(0.002)\end{array}$ & $\begin{array}{c}0.001 \\
(0.002)\end{array}$ & $\begin{array}{c}0.006^{* * *} \\
(0.002)\end{array}$ & $\begin{array}{c}0.001 \\
(0.001)\end{array}$ \\
\hline Age & $\begin{array}{c}-0.012^{* * *} \\
(0.001)\end{array}$ & $\begin{array}{c}-0.006^{* * *} \\
(0.001)\end{array}$ & $\begin{array}{c}-0.014^{* * *} \\
(0.001)\end{array}$ & $\begin{array}{c}-0.011^{* * * *} \\
(0.001)\end{array}$ & $\begin{array}{c}-0.010^{* * *} \\
(0.001)\end{array}$ & $\begin{array}{c}-0.019^{* * *} \\
(0.001)\end{array}$ & $\begin{array}{c}-0.009^{* * *} \\
(0.001)\end{array}$ \\
\hline Mother Had no Education & $\begin{array}{c}-0.068^{* * *} \\
(0.011)\end{array}$ & $\begin{array}{c}-0.094^{* * *} \\
(0.028)\end{array}$ & $\begin{array}{c}-0.056^{* * * *} \\
(0.016)\end{array}$ & $\begin{array}{l}-0.059 \\
(0.049)\end{array}$ & $\begin{array}{l}-0.022 \\
(0.033)\end{array}$ & $\begin{array}{c}-0.092^{* * * *} \\
(0.030)\end{array}$ & $\begin{array}{l}-0.022 \\
(0.035)\end{array}$ \\
\hline Mother's Education Missing & $\begin{array}{c}-0.075^{* * *} \\
(0.018)\end{array}$ & $\begin{array}{l}-0.063 \\
(0.051)\end{array}$ & $\begin{array}{c}-0.090^{* *} \\
(0.035)\end{array}$ & $\begin{array}{l}-0.071 \\
(0.083)\end{array}$ & $\begin{array}{c}0.006 \\
(0.044)\end{array}$ & $\begin{array}{l}-0.039 \\
(0.039)\end{array}$ & $\begin{array}{l}-0.081^{*} \\
(0.044)\end{array}$ \\
\hline Father Had no Education & $\begin{array}{c}-0.034^{* * *} \\
(0.012)\end{array}$ & $\begin{array}{c}0.020 \\
(0.016)\end{array}$ & $\begin{array}{c}-0.049^{* *} \\
(0.021)\end{array}$ & $\begin{array}{c}-0.086^{* * *} \\
(0.033)\end{array}$ & $\begin{array}{c}-0.064^{* *} \\
(0.030)\end{array}$ & $\begin{array}{c}0.027 \\
(0.037)\end{array}$ & $\begin{array}{l}-0.021 \\
(0.034)\end{array}$ \\
\hline Father's Education Missing & $\begin{array}{c}-0.038^{* *} \\
(0.016)\end{array}$ & $\begin{array}{l}-0.021 \\
(0.025)\end{array}$ & $\begin{array}{c}0.031 \\
(0.038)\end{array}$ & $\begin{array}{c}-0.132^{* *} \\
(0.056)\end{array}$ & $\begin{array}{l}-0.052 \\
(0.038)\end{array}$ & $\begin{array}{c}-0.080^{* *} \\
(0.040)\end{array}$ & $\begin{array}{l}-0.041 \\
(0.038)\end{array}$ \\
\hline Constant & $\begin{array}{c}0.793^{* * *} \\
(0.136)\end{array}$ & $\begin{array}{c}0.114 \\
(0.175)\end{array}$ & $\begin{array}{c}0.733^{* * *} \\
(0.268)\end{array}$ & $\begin{array}{c}1.179^{* * *} \\
(0.302)\end{array}$ & $\begin{array}{c}0.791^{* * *} \\
(0.266)\end{array}$ & $\begin{array}{c}0.797^{* *} \\
(0.353)\end{array}$ & $\begin{array}{c}0.556^{* *} \\
(0.238)\end{array}$ \\
\hline Observations & 17,990 & 3,531 & 6,847 & 2,038 & 1,291 & 2,298 & 1,985 \\
\hline R-squared & 0.248 & 0.042 & 0.115 & 0.108 & 0.144 & 0.200 & 0.052 \\
\hline
\end{tabular}

Note: Linear regression coefficients are shown, using the model outlined in equation (1), stratified by country and sex with the outcome measured as a binary indicator for having no difficulties with activities of daily living or instrumental activities of daily living. The model indicated by 'Full Sample' is a pooled regression for all countries in the sample, also stratified by sex. Standard errors account for clustering at the PSU level. India (S) refers to SAGE. 
Table A9: Concentration Indices by Country

\begin{tabular}{|c|c|c|c|c|c|c|c|}
\hline Outcome & India (S) & India $(\mathrm{L})$ & China & Ghana & Mexico & Russia & South Africa \\
\hline \multirow{3}{*}{ Lung Function } & \multicolumn{7}{|c|}{ Men } \\
\hline & $\begin{array}{c}0.043^{* * *} \\
(0.025-0.061)\end{array}$ & $\begin{array}{c}0.073^{* * *} \\
(0.041-0.104)\end{array}$ & $\begin{array}{c}0.050^{* * *} \\
(0.041-0.059)\end{array}$ & $\begin{array}{c}0.076^{* * *} \\
(0.049-0.104)\end{array}$ & $\begin{array}{c}0.059^{* * *} \\
(0.033-0.085)\end{array}$ & $\begin{array}{c}0.051^{* * *} \\
(0.026-0.076)\end{array}$ & $\begin{array}{c}0.034^{*} \\
(-0.004-0.071)\end{array}$ \\
\hline & \multicolumn{7}{|c|}{ Women } \\
\hline Grip Strength & $\begin{array}{c}0.042^{* * *} \\
(0.022-0.061)\end{array}$ & $\begin{array}{c}0.044^{* * *} \\
(0.017-0.071)\end{array}$ & $\begin{array}{c}0.051^{* * *} \\
(0.030-0.071)\end{array}$ & $\begin{array}{c}0.017 \\
(-0.014-0.048)\end{array}$ & $\begin{array}{c}0.040^{* * *} \\
(0.009-0.070)\end{array}$ & $\begin{array}{c}0.059^{* * *} \\
(0.034-0.084)\end{array}$ & $\begin{array}{c}0.089^{*} \\
(-0.002-0.181)\end{array}$ \\
\hline Lung Function & $\begin{array}{c}0.038^{* * *} \\
(0.019-0.057)\end{array}$ & $\begin{array}{c}0.039^{* * *} \\
(0.011-0.068)\end{array}$ & $\begin{array}{c}0.068^{* * *} \\
(0.060-0.077)\end{array}$ & $\begin{array}{c}0.034^{*} \\
(-0.000-0.069)\end{array}$ & $\begin{array}{c}0.064^{* * *} \\
(0.040-0.087)\end{array}$ & $\begin{array}{c}0.006 \\
(-0.030-0.041)\end{array}$ & $\begin{array}{c}0.017 \\
(-0.015-0.050)\end{array}$ \\
\hline
\end{tabular}

Note: Concentration indices for lung function, grip strength and height are shown. Samples are weighted and standard errors account for clustering at the PSU level. India (S) refers to SAGE and India (L) refers to LASI. 
Table A10: Concentration Curve Summary (Grip Strength)

\begin{tabular}{|c|c|c|c|c|}
\hline Country & Height Quantile & $\begin{array}{c}\text { Men } \\
\text { Cumulative Share of Outcome }\end{array}$ & Height Quantile & $\begin{array}{l}\text { Women } \\
\text { Cumulative Share of Outcome }\end{array}$ \\
\hline \multirow[t]{4}{*}{ India $(\mathrm{S})$} & q20 & $16.90 \%$ & $\mathrm{q} 20$ & $18.43 \%$ \\
\hline & q40 & $36.85 \%$ & $\mathrm{q} 40$ & $36.29 \%$ \\
\hline & $\mathrm{q} 60$ & $57.14 \%$ & $q 60$ & $55.47 \%$ \\
\hline & $\mathrm{q} 80$ & $77.34 \%$ & $\mathrm{q} 80$ & $76.94 \%$ \\
\hline \multirow{4}{*}{ China } & q20 & $16.82 \%$ & q20 & $17.38 \%$ \\
\hline & $\mathrm{q} 40$ & $35.99 \%$ & $\mathrm{q} 40$ & $34.22 \%$ \\
\hline & $\mathrm{q} 60$ & $54.82 \%$ & $\mathrm{q} 60$ & $54.00 \%$ \\
\hline & q80 & $76.85 \%$ & q80 & $74.47 \%$ \\
\hline \multirow[t]{4}{*}{ Ghana } & $\mathrm{q} 20$ & $15.65 \%$ & q20 & $17.45 \%$ \\
\hline & q40 & $35.90 \%$ & $\mathrm{q} 40$ & $38.28 \%$ \\
\hline & $\mathrm{q} 60$ & $54.18 \%$ & $\mathrm{q} 60$ & $57.02 \%$ \\
\hline & $\mathrm{q} 80$ & $74.76 \%$ & $\mathrm{q} 80$ & $80.61 \%$ \\
\hline \multirow[t]{4}{*}{ Mexico } & q20 & $16.88 \%$ & q20 & $16.93 \%$ \\
\hline & q40 & $37.21 \%$ & $\mathrm{q} 40$ & $36.00 \%$ \\
\hline & $\mathrm{q} 60$ & $55.99 \%$ & $\mathrm{q} 60$ & $56.17 \%$ \\
\hline & q80 & $78.81 \%$ & q80 & $77.06 \%$ \\
\hline \multirow[t]{4}{*}{ Russia } & q20 & $14.58 \%$ & q20 & $16.67 \%$ \\
\hline & $\mathrm{q} 40$ & $34.15 \%$ & $\mathrm{q} 40$ & $35.44 \%$ \\
\hline & $\mathrm{q} 60$ & $56.90 \%$ & $q 60$ & $55.64 \%$ \\
\hline & q80 & $75.96 \%$ & q80 & $76.95 \%$ \\
\hline \multirow[t]{4}{*}{ South Africa } & q20 & $15.99 \%$ & q20 & $15.58 \%$ \\
\hline & q40 & $39.72 \%$ & q40 & $33.71 \%$ \\
\hline & $\mathrm{q} 60$ & $53.29 \%$ & $\mathrm{q} 60$ & $52.46 \%$ \\
\hline & $\mathrm{q} 80$ & $77.44 \%$ & q80 & $74.90 \%$ \\
\hline \multirow[t]{4}{*}{ India (L) } & q20 & $16.50 \%$ & q20 & $15.67 \%$ \\
\hline & q40 & $32.41 \%$ & $\mathrm{q} 40$ & $33.18 \%$ \\
\hline & $\mathrm{q} 60$ & $53.47 \%$ & $q 60$ & $57.77 \%$ \\
\hline & $\mathrm{q} 80$ & $74.42 \%$ & q80 & $77.08 \%$ \\
\hline
\end{tabular}

Note: The cumulative share of the outcome is shown for each height quantile. Samples are weighted. 
Table A11: Concentration Curve Summary (Lung Function)

\begin{tabular}{|c|c|c|c|c|}
\hline Country & Height Quantile & $\begin{array}{l}\text { Men } \\
\text { Cumulative Share of Outcome }\end{array}$ & Height Quantile & $\begin{array}{l}\text { Women } \\
\text { Cumulative Share of Outcome }\end{array}$ \\
\hline \multirow[t]{4}{*}{ India $(\mathrm{S})$} & q20 & $17.54 \%$ & q20 & $17.56 \%$ \\
\hline & q40 & $37.21 \%$ & $\mathrm{q} 40$ & $37.65 \%$ \\
\hline & q60 & $57.35 \%$ & q60 & $55.04 \%$ \\
\hline & q80 & $77.70 \%$ & q80 & $77.15 \%$ \\
\hline \multirow[t]{4}{*}{ China } & q20 & $16.94 \%$ & $\mathrm{q} 20$ & $13.35 \%$ \\
\hline & $\mathrm{q} 40$ & $35.88 \%$ & $\mathrm{q} 40$ & $26.87 \%$ \\
\hline & q60 & $53.95 \%$ & $q 60$ & $43.84 \%$ \\
\hline & q80 & $76.59 \%$ & q80 & $61.91 \%$ \\
\hline \multirow[t]{4}{*}{ Ghana } & q20 & $16.21 \%$ & q20 & $19.04 \%$ \\
\hline & q40 & $33.82 \%$ & $\mathrm{q} 40$ & $38.32 \%$ \\
\hline & q60 & $53.95 \%$ & q60 & $55.35 \%$ \\
\hline & q80 & $75.57 \%$ & q80 & $76.41 \%$ \\
\hline \multicolumn{5}{|l|}{ Mexico } \\
\hline & q20 & $16.92 \%$ & q20 & $17.18 \%$ \\
\hline & q40 & $35.55 \%$ & q40 & $34.55 \%$ \\
\hline & $q 60$ & $55.25 \%$ & $q 60$ & $52.74 \%$ \\
\hline & q 80 & $78.14 \%$ & q80 & $77.49 \%$ \\
\hline \multirow[t]{4}{*}{ Russia } & q20 & $17.49 \%$ & q20 & $15.31 \%$ \\
\hline & $\mathrm{q} 40$ & $36.59 \%$ & $\mathrm{q} 40$ & $32.07 \%$ \\
\hline & q60 & $55.10 \%$ & q60 & $44.94 \%$ \\
\hline & q80 & $74.67 \%$ & q80 & $61.89 \%$ \\
\hline \multirow[t]{4}{*}{ South Africa } & q20 & $15.10 \%$ & $\mathrm{q} 20$ & $13.51 \%$ \\
\hline & q40 & $38.62 \%$ & q40 & $29.06 \%$ \\
\hline & $q 60$ & $50.80 \%$ & $q 60$ & $42.49 \%$ \\
\hline & q80 & $74.37 \%$ & $\mathrm{q} 80$ & $62.95 \%$ \\
\hline \multirow[t]{4}{*}{ India $(\mathrm{L})$} & q20 & $19.63 \%$ & q20 & $14.86 \%$ \\
\hline & $\mathrm{q} 40$ & $35.98 \%$ & $\mathrm{q} 40$ & $35.37 \%$ \\
\hline & q60 & $57.62 \%$ & q60 & $54.83 \%$ \\
\hline & q80 & $77.07 \%$ & q80 & $76.20 \%$ \\
\hline
\end{tabular}

Note: The cumulative share of the outcome is shown for each height quantile. Samples are weighted. 